\title{
BREVIAR
}

\section{Propuneri de modificări legislative privind etica universitară: forma autorilor și forma aprobată de CEMU}

\author{
Cristina Mihaela SALCĂ ROTARU ${ }^{1 *}$, Laura MANEA ${ }^{1}$ \\ 1 Universitatea Transilvania din Brașov, rotaruc@unitbv.ro \\ , manea@unitbv.ro \\ * Correspondent: rotaruc@unitbv.ro
}

Demersul anterior prezentelor modificări legislative este întins pe parcursul a peste doi ani de colaborare cu Consiliul de Etică și Management Universitar (CEMU). Un scurt istoric poate fi prezentat astfel:

În anul 2017, prin Ordinul Ministerul Educației și Cercetării nr. 4783/2017 se aprobă regulamentul de funcționare al CEMU, consiliul consultativ pe lângă Ministerul de resort:

- cu rolul de a determina și sprijini universitățile să elaboreze și să pună în practică, în mod organizat, transparent și eficient, politicile de etică și de integritate universitară, în conformitate cu prevederile legale din domeniu, în vigoare, și

- cu multiple atribuții, dintre care amintim auditarea comisiile de etică din universități.

În anul 2018, este auditată și comisia de etică a Universității Transilvania din Brașov, moment în care am ajuns la concluzia că este necesară crearea unui cadru informal de diseminare a bunelor practici ale comisiilor de etică universitară. Astfel s-a născut ideea conferinței internaționale Valorile Etice în Societatea Actuală (VESA), care a avut loc pentru prima dată în 3-5 iunie 2019, la Universitatea Transilvania din Brașov, unde au fost invitați și reprezentanți ai CEMU și Consiliul Național de Etică a Cercetării Științifice Dezvoltării Tehnologice și Inovării (CNECSDTI).

Urmare a feedback-ului pozitiv avut în iunie, în cadrul VESA 2019, în decembrie 2019 am prezentat un raport al acestor prime dezbateri naționale privind etica academică, în cadrul unei

Citation: Salcă Rotaru, C. M. \& Manea, L. (2021). Propuneri de modificări legislative privind etica universitară: forma autorilor și forma aprobată de CEMU. Revista Etică și deontologie. 1 (1), 117-152 https://doi.org/10.52744/RED.2021.01.14

Publisher's Note: RED stays neutral with regard to jurisdictional claims in published maps and institutional affiliations.

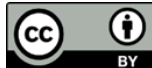

Copyright: (C) 2021 by the authors. Submitted for possible open access publication under the terms and conditions of the Creative Commons Attribution (CC BY) license (https://creativecommons.org/ licenses/by/4.0/). 
alte dezbateri - „Viitorul eticii și integrității academice. Diseminarea bunelor practici internaționale" - organizate de CEMU. Acest raport a fost axat pe prezentarea problemelor legislative și procedurale întâmpinate de comisiile de etică în activitatea lor.

- Pandemia generată de virusul SARS-COV-19, determină amânarea celei de a doua ediții a conferinței VESA pentru iunie 2021, cu menținerea legăturilor interinstituționale stabilite în 2019. Astfel, în februarie 2021, la solicitarea CEMU am făcut, la data de 25 februarie, în cadrul evenimentului „Etica și deontologia universitară în România: realități și perspective” o prezentarea detaliată a problemelor de procedură și legislative, invocate în 2019, cu denumirea „DIFICULTĂȚI ÎN FUNCȚIONAREA COMISIILOR DE ETICĂ UNVERSITARĂ GENERATE DE CADRUL ACTUAL LEGISLATIV". Această prezentare a fost baza integrării mele și a colegei lect. dr. Laura Manea în grupul constituit în vederea realizăriii unor propuneri de modificări la legislația națională cu privire la etica și integritatea academică, aprobată de CEMU prin Decizia nr. 8 din 14 iunie 2021.

Propunerile de modificare legislative, prezentate în fața CEMU și aprobate cu unele modificări, au fost prezentate initial, la data de 2 iunie 2021, în fața principalilor actori instituționali în domeniul învățământului superior, reprezentanți ai: Administrației Prezidențiale; Senatului României; Ministerului Educației, Ministerul Cercetării, Inovării și Digitalizării; Consiliului Național al Rectorilor; Agenției Română de Asigurare a Calității în Învățământul Superior (ARACIS); Unității Executive pentru Finanțarea Învățământului Superior, a Cercetării, Dezvoltării și Inovării (UEFISCDI); Consiliului Național de Etică a Cercetării Științifice, Dezvoltării Tehnologice și Inovării (CNECSDTI); Alianței Naționale a Organizațiilor Studențești din România (ANOSR).

Totodată, la acest eveniment, aceste propuneri legislative au fost prezentate și comunității academice, în special membrilor comisiilor de etică universitară, fiind lansate în dezbatere publică.

Rolul comisiilor de etică universitară, în activitatea instituțiilor, are impact asupra celor două componente - didactice și de cercetare științifică - fiind totodată componentă a răspunderii publice a instituțiilor de învățământ superior, contribuind prin transparență la menținerea unui climat etic institutional.

Prezentarea acestor propuneri de modificări legislative, și în cadrul revistei, nu este numai cel de a conștinentiza comunitatea academică cu privire la activitatea și funcționarea comisiilor de etică din universități, ci și de a determina specialiștii în domeniu să transmită opiniile lor științifice care pot aduce îmbunătățiri acestor propuneri.

Pentru claritatea demersului, acolo unde au existat diferențe între forma inițială transmisă de autoare spre CEMU și forma aprobată în final, au fost expuse ambele variante. Algoritmul modificărilor propuse a urmărit textul legal și activitatea comisiei, astfel încât actuala prezentare cuprinde și propunerile transmise către CEMU și neaprobate de acesta, în dreptul cărora se regăsește făcută această mențiune. 


\section{PROPUNERI \\ CU PRIVIRE LA MODIFICAREA CADRULUI LEGISLATIV ÎN DOMENIUL ETICII UNIVERSITARE}

\section{Introducere}

În cazul comisiilor de etică universitară se disting două mari categorii în ceea ce privește atribuțiile privitoare la respectarea normelor de etică:

\section{Etică universitară (generală)}

- Respectarea principiilor Sistemului Național de Învățământ Superior (art. 118 alin. (1) din Legea educației naționale nr. 1/2011) :

a) principiul autonomiei universitare;

b) principiul libertății academice;

c) principiul răspunderii publice;

d) principiul asigurării calității;

e) principiul echității;

f) principiul eficienței manageriale și financiare;

g) principiul transparenței;

h) principiul respectării drepturilor și libertăților studenților și ale personalului academic;

i) principiul independenței de ideologii, religii și doctrine politice;

j) principiul libertății de mobilitate națională și internațională a studenților, a cadrelor didactice și a cercetătorilor;

k) principiul consultării partenerilor sociali în luarea deciziilor;

l) principiul centrării educației pe student.

- Inadmisibilitatea discriminării pe „criterii de vârstă, etnie, sex, origine socială, orientare politică sau religioasă, orientare sexuală sau alte tipuri de discriminare, cu excepția măsurilor afirmative prevăzute de lege" (art. 118 alin. (2) din Legea educației naționale nr. 1/2011).

- Respectarea prevederilor codului de etică și deontologie profesională, care include obligatoriu (art. 130 alin. (1) din Legea educaţiei naționale nr. 1/2011):

○ stabilirea situațiilor de conflicte de interese și incompatibilități;

○ prevederea că persoanele care se află în relație de soți, afini și rude până la gradul al III-lea inclusiv nu pot ocupa concomitent funcții astfel încât unul sau una să se afle față de celălalt sau cealaltă într-o poziție de conducere, control, autoritate sau evaluare instituțională la orice nivel în aceeași universitate și nu pot fi numiți în comisii de doctorat, comisii de evaluare sau comisii de concurs ale căror decizii afectează soții, rudele sau afinii până la gradul al III-lea inclusiv;

- măsurile educaționale, administrative și tehnice care se iau pentru garantarea originalității lucrărilor de licență, master, doctorat, 


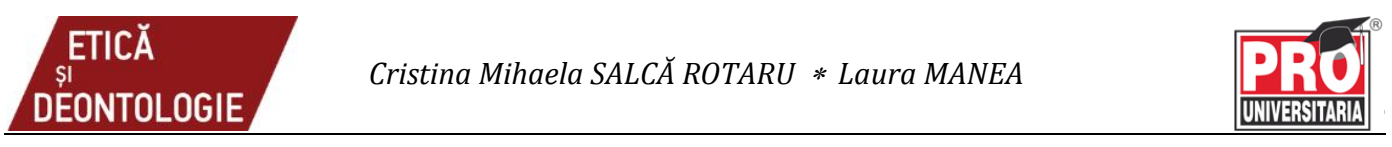

articolelor științifice sau a altor asemenea lucrări, precum și sancțiunile aferente.

2. Etica în cercetare științifică, dezvoltarea tehnologică și inovare

- Abaterile de la normele de bună conduită (art. 2 și $2^{\wedge} 1$ din Legea nr. 206/2004);

- Conflictele de interese (art. $4^{\wedge} 1$ din Legea nr. 206/2004).

Necesitatea armonizării legislative a prevederilor incidente activității comisiilor de etică universitară, este întemeiată pe cercetarea efectuată asupra:

- Prevederilor cuprinse în Legea nr. 1 din 2011 a educației naționale, Legea nr. 204/2006 privind buna conduită în cercetarea ştiinţifică, dezvoltarea tehnologică şi inovare, Legea nr. 319/2003 privind Statutul personalului de cercetare-dezvoltare, Regulamentul de organizare și funcționare a CEMU aprobat prin Ordinul MEN nr. 4.783 din 2017, Regulamentul de organizare și funcționare a CNECSDTI, aprobat prin Ordinul MEN nr. 4.655 din 2020, Metodologia privind soluționarea sesizărilor cu privire la nerespectarea standardelor de calitate sau de etică profesională, inclusiv cu privire la existența plagiatului, în cadrul unei teze de doctorat, aprobată prin Ordinul MEC nr. 5229/2020,

- a 60 Hotărâri ale Consiliului de Etică și Management Universitar,

- a 100 documente de evaluare instituțională ale ARACIS și

- a 62 de hotărâri ale instanțelor de judecată.

\section{STRUCTURA PREZENTĂRII:}

Cercetarea elementelor legislative necesar a fi armonizate este efectuată pe principalele elemente/etape care caracterizează activitatea comisiilor de etică universitară, prin identificarea acestora în diferitele acte normative incidente. Astfel la fiecare etapă se regăsesc modificările necesare clarificării acesteia şi argumente care susţin modificările propuse, respectiv situaţii practice identificate şi analizate.

Articole care conțin prevederi aferente mai multor elemente/etape se regăsesc cu modificările corespunzătoare la fiecare dintre acestea.

În anexa TABEL FINAL se regăsește forma finală a propunerilor de modificare legislativă a fiecărui articol transmisă către CEMU, iar acolo unde este cazul sunt coroborate toate propunerile de modificare, intermediare, aferente elementelor/etapelor. Formele finale a propunerilor de modificare legislativă a articolelor sunt grupate pe acte normative.

\section{Înființarea, componența și mandatul comisiei de etică universitară}

1. Conform art. 199 alin. (1) din Legea educației naționale nr. 1/2011 (LEN), studenții sunt considerați parteneri ai instituțiilor de învățământ superior și membri egali ai comunității academice. În baza principiului participării la decizie, care reglementează activitatea studenților în cadrul comunității universitare (art. 202 alin. (1) lit.c) din LEN), și în conformitate cu art. 213 din LEN studenții trebuie să aibă 
cel puțin un reprezentant în comisiile de etică. Alegerea acestuia se face de către studenți, în mod democratic, prin vot universal, direct și secret, la nivelul diverselor formații, programe sau cicluri de studiu, atât în cadrul facultăților, cât și al universității. Conducerea instituției de învățământ superior nu se implică în organizarea procesului de alegere a reprezentanților studenților.

- Deoarece există comisii de etică în structura cărora nu se regăsesc reprezentanți ai studenților ca urmare a modului de numirea a comisiei de etică, este necesară reafirmarea importanței existenței a cel puțin unui reprezentant al studenților în comisiile de etică.

- Deoarece există comisii de etică în structura cărora nu se regăsesc reprezentanți ai studenților ca urmare a nefinalizării la nivelul organizațiilor studențești a procedurilor de desemnare, situație care nu poate constitui impediment în numirea comisiei de etică universitară sau în funcționarea legală a acesteia, este necesară stabilirea unei modalități pentru respectarea cerinței imperative a existenței a cel puțin unui reprezentant al studenților în comisiile de etică universitară.

2. LEN prevede, pentru diferite structuri de conducere/decizie din instituţiile de învățământ superior, mandate de de 4 ani.

- Deoarece pentru funcționarea Comisie de etică, LEN nu prevede perioada unui mandat iar la nivelul instituțiilor de învățământ superior sunt stabilite în mod divers mandatul acestora, este necesară armonizarea prevederilor și introducerea unei perioade a mandatului acestei comisii, coroborat cu perioada de mandat a forurilor decizionale.

\section{A. Variantă propusă de autoare către CEMU}

Propunere de modificare legislativă LEN: este necesară modificarea art. 306 din LEN prin introducerea a două noi alineate: alin. (11) și alin. (21) și prin modificare și completare alin. (2).

\begin{tabular}{|c|c|c|c|}
\hline $\begin{array}{l}\text { Nr. } \\
\text { crt. }\end{array}$ & Articol & Text inițial & Text propus \\
\hline 1. & $\begin{array}{l}\text { Art. } 306 \text { alin. (2), } \\
\text { LEN nr. 1/2011 }\end{array}$ & $\begin{array}{l}\text { Articolul } 306 \\
\text { (2) Structura și componența } \\
\text { comisiei de etică universitară este } \\
\text { propusă de consiliul de administra- } \\
\text { ție, avizată de senatul universitar și } \\
\text { aprobată de rector. Membrii comi- } \\
\text { siei sunt persoane cu prestigiu } \\
\text { profesional și autoritate morală. Nu } \\
\text { pot fi membri ai comisiei de etică } \\
\text { universitară persoanele care ocupă } \\
\text { vreuna dintre funcțiile: rector, pro- } \\
\text { rector, decan, prodecan, director } \\
\text { administrativ, director de depar- } \\
\text { tament sau de unitate de cercetare- } \\
\text { dezvoltare, proiectare, micropro- } \\
\text { ducție. }\end{array}$ & $\begin{array}{l}\text { Articolul } 306 \\
\left(1^{1}\right) \text { Mandatul comisiei este de } 4 \text { ani. } \\
\text { (2) Structura și componența } \\
\text { comisiei de etică universitară este } \\
\text { propusă de consiliul de adminis- } \\
\text { trație, avizată de senatul univer- } \\
\text { sitar și numită de rector, cu } \\
\text { respectarea prevederilor art. } 213 \\
\text { alin (14). } \\
\left(2^{1}\right) \text { Membrii comisiei sunt persoane } \\
\text { cu prestigiu profesional și autoritate } \\
\text { morală. Nu pot fi membri ai comisiei } \\
\text { de etică universitară persoanele care } \\
\text { ocupă vreuna dintre funcțiile: rector, } \\
\text { prorector, decan, prodecan, director }\end{array}$ \\
\hline
\end{tabular}




\begin{tabular}{|c|c|c|c|}
\hline $\begin{array}{l}\text { Nr. } \\
\text { crt. }\end{array}$ & Articol & Text inițial & Text propus \\
\hline & & & $\begin{array}{l}\text { administrativ, director de departa- } \\
\text { ment sau de unitate de cercetare- } \\
\text { dezvoltare, proiectare, micropro- } \\
\text { ducție. În situația nefinalizării proce- } \\
\text { durilor prevăzute de art. } 203 \text { alin. (2) } \\
\text { pentru desemnarea reprezentantu- } \\
\text { lui studenților în comisia de etică, } \\
\text { reprezentantul studenților în consi- } \\
\text { liul de administrație devine de drept } \\
\text { membru al comisiei de etică, până la } \\
\text { finalizarea procedurilor de } \\
\text { desemnare. }\end{array}$ \\
\hline
\end{tabular}

\section{B. Variantă aprobată de CEMU}

\begin{tabular}{|c|c|c|c|}
\hline $\begin{array}{l}\text { Nr. } \\
\text { crt. }\end{array}$ & Articol & Text inițial & Text propus \\
\hline 1. & $\begin{array}{l}\text { Art. } 306 \text { alin. (2), } \\
\text { LEN nr. 1/2011 }\end{array}$ & $\begin{array}{l}\text { Articolul } 306 \\
\text { (2) Structura și componența } \\
\text { comisiei de etică universitară este } \\
\text { propusă de consiliul de adminis- } \\
\text { trație, avizată de senatul universi- } \\
\text { tar și aprobată de rector. Membrii } \\
\text { comisiei sunt persoane cu prestigiu } \\
\text { profesional și autoritate morală. Nu } \\
\text { pot fi membri ai comisiei de etică } \\
\text { universitară persoanele care ocupă } \\
\text { vreuna dintre funcțiile: rector, } \\
\text { prorector, decan, prodecan, } \\
\text { director administrativ, director de } \\
\text { departament sau de unitate de } \\
\text { cercetare-dezvoltare, proiectare, } \\
\text { microproducție. }\end{array}$ & $\begin{array}{l}\text { Articolul } 306 \\
\left(2^{1}\right) \text { Mandatul comisiei de etică } \\
\text { universitară este de } 4 \text { ani. } \\
\left(2^{2}\right) \text { Structura și componența } \\
\text { comisiei de etică universitară este } \\
\text { propusă de consiliul de adminis- } \\
\text { trație, avizată de senatul univer- } \\
\text { sitar și numită de rector, cu } \\
\text { respectarea prevederilor art. } 213 \\
\text { alin (14). } \\
\left(2^{3}\right) \text { Membrii comisiei sunt per- } \\
\text { soane cu prestigiu profesional și } \\
\text { autoritate morală. Nu pot fi membri } \\
\text { ai comisiei de etică universitară } \\
\text { persoanele care ocupă vreuna } \\
\text { dintre funcțiile: rector, prorector, } \\
\text { decan, prodecan, director adminis- } \\
\text { trativ, director de departament sau } \\
\text { de unitate de cercetare-dezvoltare, } \\
\text { proiectare, microproducție. } \\
\text { Varianta } 1 \\
\text { (24) Reprezentanții studenților în } \\
\text { comisiile de etică universitară sunt } \\
\text { aleși de către studenții reprezen- } \\
\text { tanți în Senatul universitar. } \\
\text { Varianta } 2 \\
\text { (24) Reprezentanții studenților în } \\
\text { comisiile de etică universitară sunt } \\
\text { aleși în conformitate cu modalita- } \\
\text { tea stabilită de organizațiile stu- } \\
\text { dențești legal constituite la nivelul } \\
\text { universității. În lipsa acestora, } \\
\text { modalitatea de alegere se va stabili } \\
\text { de către studenții reprezentanți în } \\
\text { Senatul universitar. }\end{array}$ \\
\hline
\end{tabular}


- Deoarece în atribuțiile comisiilor de etică universitară intră și atribuțiile prevăzute în Legea 206 din 2004 privind buna conduită în cercetarea științifică, dezvoltarea tehnologică și inovare care reglementează conduita etică în domeniu precum și cercetarea și sancționarea faptelor care contravin de la aceasta,

- Deoarece LEN, care este ulterioară Legii 206 din 2004, vine cu reglementări specifice pentru comisiile de etică în instituțiile de învățământ superior,

Este necesară armonizarea prevederilor celor două acte normative sub aspectul stabilirii cu claritate, cu privire la comisiile de etică universitară, a autorității de înființare și a componenței prin delimitare față de comisiile de etică din cadrul unităților și instituțiilor de cercetare.

\section{A. Variantă propusă de autoare către CEMU}

Propunere de modificare legislativă Legea 206/2004: este necesară modificarea art. 9 din Legea nr. 206/2004 prin introducere de noi alineate - alin. (21)și alin. (31); modificarea și completarea alin. (2) și (3).

\begin{tabular}{|c|c|c|c|}
\hline 2. & $\begin{array}{l}\text { Art. } 9 \text { alin. (2) } \\
\text { și (3), Legea } \\
\text { nr. 206/2004 }\end{array}$ & $\begin{array}{l}\text { Articolul 9 } \\
\text { (2) În cadrul unităților şi al insti- } \\
\text { tuțiilor prevăzute la alin. (1) se } \\
\text { înființează comisii de etică, pe } \\
\text { lângă consiliile ştiințifice sau, după } \\
\text { caz, pe lângă consiliile de } \\
\text { administrație } \\
\text { (3) Componența comisiilor de etică } \\
\text { este propusă de consiliile științifice } \\
\text { sau, după caz, de consiliile de } \\
\text { administrațieși se aprobă prin } \\
\text { ordin al conducătorului instituției } \\
\text { sau al unității prevăzute la alin. (1). }\end{array}$ & $\begin{array}{l}\text { (2) În cadrul unităților şi al } \\
\text { instituțiilor de cercetare prevăzute } \\
\text { la alin. (1) se înființează comisii de } \\
\text { etică, pe lângă consiliile ştiințifice } \\
\text { sau, după caz, pe lângă consiliile de } \\
\text { administrație. } \\
\left(2^{1}\right) \text { În cadrul instituțiilor de } \\
\text { învățământ superior prevăzute la } \\
\text { alin. (1) se înființează comisii de } \\
\text { etică, ca organism decizional, } \\
\text { independent, pe lângă Senatul } \\
\text { universitar. } \\
\text { (3) Componența comisiilor de etică ă } \\
\text { prevăzute la alin. (2) este propusă } \\
\text { de consiliile științifice sau, după } \\
\text { caz, de consiliile de administrație şi } \\
\text { se aprobă prin ordin al conducă- } \\
\text { torului instituției sau al unității } \\
\text { prevăzute la alin. (1). } \\
\text { (31) Componența comisiilor de } \\
\text { etică prevăzute la alin. (21) se } \\
\text { stabilește conform prevederilor } \\
\text { Legii } 1 \text { din } 2011 \text { legea educației } \\
\text { nationale }\end{array}$ \\
\hline
\end{tabular}




\section{B. Variantă aprobată de CEMU}

\begin{tabular}{|c|c|c|}
\hline $\begin{array}{l}\text { Art. } 9 \text { alin. (2) și } \\
\text { (3), Legea } \\
\text { nr. 206/2004 }\end{array}$ & $\begin{array}{l}\text { Articolul } 9 \\
\text { (2) În cadrul unitățilorşi al institu- } \\
\text { țiilor prevăzute la alin. (1) se } \\
\text { înființează comisii de etică, pe lângă } \\
\text { consiliile ştiințifice sau, după caz, pe } \\
\text { lângă consiliile de administrație } \\
\text { (3) Componența comisiilor de etică } \\
\text { este propusă de consiliile științifice } \\
\text { sau, după caz, de consiliile de } \\
\text { administrațieși se aprobă prin } \\
\text { ordin al conducătorului instituției } \\
\text { sau al unității prevăzute la alin. (1). }\end{array}$ & $\begin{array}{l}\text { (2) În cadrul unităților ş̧i al } \\
\text { instituțiilor de cercetare prevăzute } \\
\text { la alin. (1) se înființează comisii de } \\
\text { etică, pe lângă consiliile ştiințifice } \\
\text { sau, după caz, pe lângă consiliile de } \\
\text { administrație. } \\
\left(2^{1}\right) \text { În cadrul instituțiilor de } \\
\text { învățământ superior prevăzute la } \\
\text { alin. (1) se înființează comisii de } \\
\text { etică, ca organism decizional, a cărui } \\
\text { componență este propusă de consi- } \\
\text { liul de administrație, avizată de } \\
\text { senatul universitar și numită de } \\
\text { rector. } \\
\text { (3) Componența comisiilor de etică } \\
\text { prevăzute la alin. (2) este propusă } \\
\text { de consiliile științifice sau, după } \\
\text { caz, de consiliile de administrație și } \\
\text { se aprobă prin ordin al conducă- } \\
\text { torului instituției sau al unității } \\
\text { prevăzute la alin. (1). } \\
\text { (31) Componența comisiilor de } \\
\text { etică prevăzute la alin. (21) se sta- } \\
\text { bilește conform prevederilor Legii } \\
\text { educatiei nationale nr. } 1 \text { din } 2011 \text {. }\end{array}$ \\
\hline
\end{tabular}

\section{Independența comisiei de etică universitară}

Comisia de etică universitară, în activitatea sa de cercetare a faptelor prin care sunt încălcate principiile și valorile eticii universitare, trebuie să fie un organism independent și echidistant față de orice structură de conducere a unei instituții de învățământ superior.

- Deoarece există situații în care Raportul/Hotărârea Comisiei de etică universitară este avizat/ă de Consiliul de administrație al unei instituții de învățământ superior sau de către Senatul Universitar înainte de a fi pusă în aplicarea decizia acesteia ${ }^{1}$,

- Deoarece în rapoartele de evaluare ARACIS² se regăsesc situații în care subordonarea față de structurile de conducere sau chiar existența CEU ca o componentă a Senatului, este considerată legală sau chiar indicată de

\footnotetext{
${ }^{1}$ Decizia nr. 301/2019 din 21-ian-2019, Tribunalul Bucuresti, contestatie decizie de sanctionare (Litigii de muncă), unde se aratăcă „prin decizia Rectorului nr. 355/28.06.2018, se ia act de concluziile Comisiei de Etică Universitară, precum şi de sancțiunea propusă de aceasta, astfel cum au fost aprobate de Senatul Universității, fiind sancționat cu „avertisment scris". Consilierul juridicarată: Decizia nr. 355/28 iunie 2018 este temeinică și legală fiind aplicată de către rectorul USAMVB ca urmare a stabilirii sancțiunii de către Senatul universitar al USAMVB pe probleme de etică universitară și nicidecum de decanul FMVB, pe probleme de disciplină a muncii; decizia în speță cuprinde toate elementele prevăzute de lege şi Regulamentul Comisiei de Etică, inclusive termenul şi autoritatea la care se poate contesta - CEMU."

2 C.M. Salcă Rotaru, Rolul eticii și comisiilor de etică în asigurarea calității în învățământul universitar românesc, Quality Assurance Review for Higher Education, Vol. 8, No. 2, 2018, pp. 25-40, în care sunt studiate 78 de evaluări instituționale ARACIS din perioada 2014-2018.
} 
evaluatori, sau aceeași formă de subordonare este constatată prin modul de aprobare a deciziilor CEU de către Senat fără a fi considerată neconformitate,

- Deoarece independența Comisiei de etică universitară, nu este formulată în mod explicit, dar intenția legiuitorului reiese din modul în care este aprobată structura și componența acestei (art. 306 LEN), precum și a modului în care este luată o hotărâre (art. 307 LEN), respectiv este pusă în aplicare (art. 322 LEN),

- În vederea evitării unor ingerințe în activitatea Comisiilor de etică universitară, din partea diferitelor structuri din cadrul instituției de învățământ superior, este necesară reafirmarea caracterului independent al acestor comisii și stabilirea de sancțiuni pentru situațiile în care se aduce atingere independenței acestora.

\section{A. Variantă propusă de autoare către CEMU}

Propunere de modificare legislativă LEN: este necesară modificarea art. 306 din LEN prin completarea alin. (1).

\begin{tabular}{|c|c|l|l|}
\hline $\begin{array}{c}\text { Nr. } \\
\text { crt. }\end{array}$ & Articol & \multicolumn{1}{|c|}{ Text inițial } & \multicolumn{1}{c|}{ Text propus } \\
\hline 3. & Art. 306 alin. (1), & $\begin{array}{l}\text { Articolul 306 } \\
\text { (1) La nivelul fiecărei universități } \\
\text { Lencționează comisia de etică }\end{array}$ & $\begin{array}{l}\text { Articolul 306 } \\
\text { (1) La nivelul fiecărei universități } \\
\text { universitară. }\end{array}$ \\
& & $\begin{array}{l}\text { funcționează comisia de etică } \\
\text { universitară, organism decizional, } \\
\text { independent, pe lângă Senatul } \\
\text { universitar. Nerespectarea inde- } \\
\text { pendenței CEU în activitatea sa } \\
\text { constituie încălcare a art. 124 } \\
\text { alin. (1) lit. a). }\end{array}$ \\
\hline
\end{tabular}

\section{B. Variantă aprobată de CEMU}

\begin{tabular}{|c|c|c|c|}
\hline $\begin{array}{l}\text { Nr. } \\
\text { crt. }\end{array}$ & Articol & Text inițial & Text propus \\
\hline & $\begin{array}{l}\text { Art. } 306 \text { alin. (1), } \\
\text { LEN nr. 1/2011 }\end{array}$ & $\begin{array}{l}\text { Articolul } 306 \\
\text { (1) La nivelul fiecărei universități } \\
\text { funcționează comisia de etică } \\
\text { universitară. }\end{array}$ & $\begin{array}{l}\text { Articolul } 306 \\
\text { (1) La nivelul fiecărei universități } \\
\text { funcționează comisia de etiă } \\
\text { universitară, organism decizional, } \\
\text { independent. Hotărârile comisiei de } \\
\text { etică universitară sunt puse în } \\
\text { aplicare de către structurile abilitate } \\
\text { fără alte avize decât cel prevăzut la } \\
\text { art. } 307 \text {. Senatul universitar, } \\
\text { Consiliul de administrație sau } \\
\text { oricare altă structură dintr-o } \\
\text { universitate nu poate interfera în } \\
\text { procesul decizional al comisie de } \\
\text { etică universitară. Nerespectarea } \\
\text { acestei prevederi constituie o } \\
\text { încălcare a art. } 124 \text { alin. (1) lit. a). }\end{array}$ \\
\hline
\end{tabular}


Atributiile comisiei de etică universitară, proceduri de lucru și avizarea documentelor

Atribuțiile comisie de etică universitară acoperă două componente principale: etica universitară generală, pentru respectarea principiilor Sistemului Național de Învățământ Superior (art. 118 alin. (1) din LEN) și prevenirea și sancționarea discriminării, și etica în cercetare științifică, dezvoltarea tehnologică și inovare, conform Legii 206 din 2004.

0 parte a activității Comisiilor de etică universitară se poate desfășura ca urmare a sesizărilor primite din partea organismelor specializate astfel:

- CEMU, aflat în coordonarea Ministerului Educației, care se pronunță asupra litigiilor de etică universitară și analizează cazurile referitoare la abateri de la normele de etică și management universitar, în urma sesizărilor sau prin autosesizare, conform legii, după ce subiectul lor a fost analizat în cadrul universității (art. 19 al Regulamentului de organizare și funcționare al CEMU, aprobat prin Ordinul MEN nr. 4.783 din 2017).

- CNACDTU, aflat în coordonarea Ministerului Educației, prin intermediul IOSUD pentru existența plagiatului în cuprinsul tezelor de doctorat, care solicită IOSUD, în vederea constituirii dosarului de analiză a sesizării, un punct de vedere fundamentat în principal pe hotărârea Comisei de etică universitară (art. 6, lit.e) din Metodologie).

- CNECSDTI, aflat în coordonarea Ministerului Cercetării Inovării și Digitalizării, care analizează cazurile referitoare la încălcarea normelor de bună conduită, în urma sesizărilor/contestațiilor sau prin autosesizare și emite hotărâri prin care se constată dacă a fost realizată o abatere de la normele de bună conduită (art. 4 lit. d) și e) din Regulamentul de organizare si funcționare a CNECSDTI, aprobat prin Ordinul MEN nr. 4.655 din 2020). În afara contestațiilor, CNECSDTI transmite sesizarea către conducerea unității sau instituției de cercetare-dezvoltare, în vederea analizei de către comisia de etică a acesteia, conform prevederilor Legii 206 din 2004 care arată la art. $4^{\wedge} 2$ că: sesizările privind abaterile de la normele de bună conduită în activitatea de cercetare-dezvoltare sunt analizate în două etape, prima etapă fiind analiza la nivelul instituției în cadrul căreia presupusele abateri s-au produs.

În prezent procedurile în fața Comisiei de etică universitară se desfășoară și finalizează astfel:

- Conform LEN (art. 309 teza 1) comisia de etică universitară demarează procedurile stabilite de Codul de etică și deontologie universitară, respectiv de Legea nr. 206/2004 și elaborează hotărâri care sunt avizate de consilierul juridic al universității. Prin urmare, conform LEN, atât cercetarea abaterilor de la etica generală cât și a abaterilor de la buna conduită în cercetarea științifică, se finalizează cu hotărâri. Acestea sunt actele juridice care sunt puse în aplicare de către rector, conform prevederilor art. 322 din LEN; 


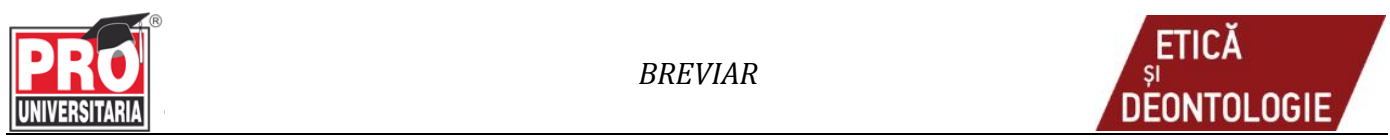

- Conform Legii nr. 206/2004 comisiile de etică numesc comisii de analiză pentru examinarea sesizărilor (art. 10). Comisia de analiză elaborează un raport care se aprobă de către comisia de etică (art. 11) și este avizat de către consilierul juridic al instituției. Prin urmare contestațiile depuse în fața CNECSDTI au în vedere rapoartele emise de comisia de etică universitară. Comisia de etică universitară, fiind un organism de cercetare și sancționare din cadrul instituției de învățământ superior, rectorul universității nu poate pune în aplicare un raport al comisie de analiză (art. 307, art. 309 teza 1 raportate la art. $322 \mathrm{LEN}$ ).

- Constituirea dosarului de analiză pentru sesizările în fața CNADCTU, face referire la hotărârea Comisiei de etică universitară, avizată juridic (art. 6, lit. e) din Metodologie). Plagiatul este o faptă ce contravine eticii universitare și este cercetată și sancționată în baza prevederilor Legii nr. 206/2004.

Complexitatea sesizărilor, atât sub aspectul obiectului lor cât și sub aspectul respectării principiilor de drept, cu precădere a principiului legalității, face necesară și utilă prezenta unor specialiști la ședințele comisiei de etică universitară/comisiei de analiză.

Practica comună arată că există deja o serie de comisii de etică universitară care au în componență un astfel de consilier juridic.

Totuși, o persoană care participă direct la procesul decizional nu poate să confere ulterior și un aviz de legalitate, conform art. 307 din LEN și art. 11 din Legea nr. 206/2004. Persoana în cauză poate fi invitată, însă modul în care participă la ședințele comisiei de etică universitară nu este reglementat.

Ca urmare,

- deoarece aceste acte normative stabilesc atribuții și proceduri generale, diferite pentru aceeași comisie,

- deoarece aceste acte normative impun emiterea de documente finale diferite în urma derulării procedurii specifice în fața comisie de etică universitară,

- deoarece aceste neconcordanțe se regăsesc și în reglementările interne, emise de instituțiile de învățământ superior în baza autonomiei universitare (Cartă și regulamentele comisiilor de etică) cu efect și asupra activității CEMU și CNECSDTI.

Este necesară armonizarea prevederilor din LEN şi a celor din Legea nr. 206/2004 sub aspectul componenței comisiilor de etică/comisiilor de analiză, procedurilor comisiilor de etică și al actelor emise de acestea.

\section{A. Variantă propusă de autoare către CEMU}

Propunere de modificare legislativă:

- este necesară modificarea art. 306 alin. (3) din LEN prin modificarea lit. a) și lit. e) și introducerea lit. $\mathrm{a}^{1}$ );

- este necesară modificarea art. 309 teza 1 din LEN;

- este necesară introducerea unui nou articol după articolul 309: art. 3091; 
- este necesară modificarea art. 11 din Legea 206/2004 prin completarea alin. (3) și introducerea a două noi alineate, alin. ( $\left.3^{1}\right)$ și $\left(3^{2}\right)$;

- este necesară modificarea art. 21 din Regulamentul de organizare și funcționare al CNECSDTI, aprobat prin Ordinul 4655 din 2020, prin completarea lit.a).

Strâns legat de trecerea termenului de soluționare se află procedura comunicării. Legea prevede doar comunicarea către partea reclamantă, însă o importanță deosebită o are și comunicarea către partea reclamată/sancționată, deoarece de la aceste moment curg termenele de contestare. Și în acest sens este necesară modificarea prevederilor art. 11 din Legea nr. 206/2004.

\begin{tabular}{|c|c|c|c|}
\hline $\begin{array}{l}\text { Nr. } \\
\text { crt. }\end{array}$ & Articol & Text inițial & Text propus \\
\hline 4. & $\begin{array}{l}\text { Art. } 306 \text { alin. (3), } \\
\text { LEN nr. } 1 / 2011\end{array}$ & $\begin{array}{l}\text { Articolul } 306 \\
\text { (3) Comisia de etică universitară } \\
\text { are următoarele atribuții: } \\
\text { a) analizează și soluționează } \\
\text { abaterile de la ețica universitară, } \\
\text { pe baza sesizărilor sau prin } \\
\text { autosesizare, conform Codului de } \\
\text { etică și deontologie universitară; } \\
\text { e) alte atribuții prevăzute de } \\
\text { prezenta lege sau stabilite conform } \\
\text { Cartei universitare, conform legii. }\end{array}$ & $\begin{array}{l}\text { Articolul } 306 \\
\text { (3) Comisia de etică universitară } \\
\text { are următoarele atribuții: } \\
\text { a) numesc comisii de analiză } \\
\text { pentru examinarea sesizărilor } \\
\text { referitoare la abaterile de la etica } \\
\text { universitară, pe baza sesizărilor } \\
\text { sau prin autosesizare, conform } \\
\text { Codului de etică și deontologie } \\
\text { universitară; } \\
\text { a1) soluționează abaterile de la } \\
\text { etica universitară prin emiterea } \\
\text { unei hotărâri în baza raportului } \\
\text { comisiei de analiză. Raportul } \\
\text { comisiei de analiză face parte } \\
\text { integrantă din hotărârea comisiei } \\
\text { de etică. } \\
\text { e) alte atribuții prevăzute de lege } \\
\text { sau stabilite conform Cartei } \\
\text { universitare, conform legii. }\end{array}$ \\
\hline 5. & $\begin{array}{l}\text { Art. } 309 \text { teza } 1 \text {, } \\
\text { LEN nr. } 1 / 2011\end{array}$ & $\begin{array}{l}\text { Articolul } 309 \\
\text { În urma unei sesizări, comisia de } \\
\text { etică universitară demarează pro- } \\
\text { cedurile stabilite de Codul de etică și } \\
\text { deontologie universitară, respectiv } \\
\text { de Legea nr. } 206 / 2004 \text {, cu modi- } \\
\text { ficările și completările ulterioare. } \\
\text { Comisia răspunde autorului } \\
\text { sesizării în termen de } 30 \text { de zile de } \\
\text { la primirea sesizării și îi comunică } \\
\text { acestuia rezultatul procedurilor, } \\
\text { după încheierea acestora. }\end{array}$ & $\begin{array}{l}\text { Articolul } 309 \\
\text { În urma unei sesizări, comisia de } \\
\text { etică universitară demarează proce- } \\
\text { durile stabilite de prezenta lege, de } \\
\text { Codul de etică și deontologie } \\
\text { universitară, respectiv de Legea } \\
\text { nr. 206/2004, cu modificările și } \\
\text { completările ulterioare. }\end{array}$ \\
\hline 6 & - & - & $\begin{array}{l}\text { Articolul } 3091 \\
\text { (1) La ședințele comisiei de etică } \\
\text { universitară, respectiv a comisiilor } \\
\text { de analiză, pot participa în calitate }\end{array}$ \\
\hline
\end{tabular}




\begin{tabular}{|c|c|c|c|}
\hline $\begin{array}{l}\text { Nr. } \\
\text { crt. }\end{array}$ & Articol & Text inițial & Text propus \\
\hline & & & $\begin{array}{l}\text { de invitați, persoane cu experiență } \\
\text { în domeniul sesizării. } \\
\text { (2) Propunerea de invitare se } \\
\text { motivează, se poate face de către } \\
\text { orice membru al comisiei și se } \\
\text { aprobă cu votul majorității simple a } \\
\text { membrilor comisiei de etică } \\
\text { universitară. } \\
\text { (3) Persoanele invitate nu au drept } \\
\text { de vot. Opinia acestora este } \\
\text { consultativă și se menționează în } \\
\text { procesele verbale ale ședințelor la } \\
\text { care au participat. } \\
\text { (4) Poate avea calitatea de invitat } \\
\text { consilierul juridic al instituției. }\end{array}$ \\
\hline 7. & $\begin{array}{l}\text { Articolul } 11 \\
\text { Legea nr. } \\
\text { 206/2004 }\end{array}$ & $\begin{array}{l}\text { Articolul 11 } \\
\text { (3) Comisia de analiză elaborează } \\
\text { un raport care se aprobă de către } \\
\text { comisia de etică, se comunică } \\
\text { autorului sesizării în scris şi se face } \\
\text { public pe site-ul web al instituției } \\
\text { în termen de } 45 \text { de zile calenda- } \\
\text { ristice de la primirea sesizării; în } \\
\text { cazul constatării unor abateri de la } \\
\text { normele de bună conduită în } \\
\text { activitatea de cercetare-dezvoltare, } \\
\text { raportul numeşte persoanele } \\
\text { vinovate şi stabilește una sau mai } \\
\text { multe dintre sancțiunile prevăzute } \\
\text { la art. } 11^{\wedge} 1 \text {; persoanele vinovate } \\
\text { pot fi diferite de persoanele vizate } \\
\text { în textul sesizării. } \\
\text { (4) Raportul comisiei de analiză } \\
\text { este avizat de către consilierul } \\
\text { juridic al instituției. Răspunderea } \\
\text { juridică pentru hotărârile şi } \\
\text { activitatea comisiei de analiză } \\
\text { revine instituției. } \\
\text { (5) Raportul comisiei de analiză } \\
\text { poate fi contestat la Consiliul } \\
\text { Național de Etică de către persoana } \\
\text { sau persoanele găsite vinovate ori } \\
\text { de către autorul sesizării; contes- } \\
\text { tația va conține obligatoriu o copie } \\
\text { simplă după sesizarea inițialăşi } \\
\text { după raportul comisiei de analiză. } \\
\text { (6) În cazul în care o contestație nu } \\
\text { a fost înaintată către Consiliul } \\
\text { Național de Etică în termen de } 15 \\
\text { zile lucrătoare de la data } \\
\text { comunicării prevăzute la alin. (3), } \\
\text { sancțiunile stabilite de comisia de }\end{array}$ & $\begin{array}{l}\text { Articolul 11 } \\
\text { (3) Comisia de analiză elaborează } \\
\text { un raport care se aprobă prin } \\
\text { hotărâre de către comisia de etică, } \\
\text { se comunică părților, în scris, şi se } \\
\text { face publice pe site-ul web al } \\
\text { instituției în termen de } 45 \text { de zile } \\
\text { calendaristice de la primirea sesi- } \\
\text { zării; în cazul constatării unor } \\
\text { abateri de la normele de bună } \\
\text { conduită în activitatea de cercetare- } \\
\text { dezvoltare, raportul numeşte per- } \\
\text { soanele vinovate şi stabilește una } \\
\text { sau mai multe dintre sancțiunile } \\
\text { prevăzute la art. } 11^{\wedge} 1 \text {; persoanele } \\
\text { vinovate pot fi diferite de } \\
\text { persoanele vizate în textul sesizării. } \\
\text { (31) Raportul comisie de analiză } \\
\text { face parte integrantă din hotărârea } \\
\text { comisiei de etică. } \\
\text { (3²) În termen de } 10 \text { zile de la } \\
\text { emiterea hotărârii comisiei de etică, } \\
\text { sancțiunile stabilite în aceasta sunt } \\
\text { puse în aplicare prin decizie a } \\
\text { conducătorului. Decizia se comu- } \\
\text { nică persoanei găsite vinovate. } \\
\text { (4) Hotărârea comisiei de etică este } \\
\text { avizată de către consilierul juridic } \\
\text { al instituției. Răspunderea juridică } \\
\text { pentru hotărârile şi activitatea } \\
\text { comisiei de etică revine instituției. } \\
\text { (5) Hotărârea comisiei de etică } \\
\text { împreună cu decizia de sancționare, } \\
\text { atunci când este cazul, pot fi } \\
\text { contestate în condițiile alin. (6) la } \\
\text { Consiliul Național de Etică de către } \\
\text { persoana sau persoanele găsite }\end{array}$ \\
\hline
\end{tabular}




\begin{tabular}{|c|c|c|c|}
\hline $\begin{array}{l}\mathrm{Nr} \text {. } \\
\text { crt. }\end{array}$ & Articol & Text inițial & Text propus \\
\hline & & $\begin{array}{l}\text { analiză sunt puse în aplicare de } \\
\text { către conducătorul instituției sau } \\
\text { de către consiliul de administrație, } \\
\text { după caz, în termen de } 45 \text { de zile } \\
\text { calendaristice de la data comuni- } \\
\text { cării raportului conform alin. (3). }\end{array}$ & $\begin{array}{l}\text { vinovate ori de către autorul } \\
\text { sesizării; contestația va conține } \\
\text { obligatoriu o copie simplă după } \\
\text { sesizarea inițială şi după hotărârea } \\
\text { comisiei de etică și se comunică } \\
\text { obligatoriu și instituției emitente. } \\
\text { (6) În cazul în care o contestație nu a } \\
\text { fost înaintată către Consiliul } \\
\text { Național de Etică în termen de } 15 \\
\text { zile lucrătoare de la data comunicării } \\
\text { prevăzute la alin. }\left(3^{2}\right) \text {, sancțiunile } \\
\text { stabilite de comisia de etică prin } \\
\text { decizia conducătorului instituției } \\
\text { sau de către consiliul de adminis- } \\
\text { trație, după caz, devin executorii. }\end{array}$ \\
\hline 8. & $\begin{array}{c}\text { Articolul 21 } \\
\text { Regulamentul de } \\
\text { organizare și } \\
\text { funcționare al } \\
\text { CNECSDTI, } \\
\text { aprobat prin } \\
\text { Ordinul } 4655 \text { din } \\
2020\end{array}$ & $\begin{array}{l}\text { Articolul 21 } \\
\text { (1) CNECSDTI este obligat să } \\
\text { analizeze cazurile sesizate în } \\
\text { oricare dintre următoarele situații: } \\
\text { a) atunci când la sesizare sau } \\
\text { contestație este anexată o copie } \\
\text { simplă, în format scris ori } \\
\text { electronic, după raportul elaborat } \\
\text { de către comisia de analiză din } \\
\text { cadrul unității sau instituției în } \\
\text { care presupusa abatere s-a produs; }\end{array}$ & $\begin{array}{l}\text { Articolul 21 } \\
\text { (1) CNECSDTI este obligat să } \\
\text { analizeze cazurile sesizate în } \\
\text { oricare dintre următoarele situații: } \\
\text { a) atunci când la sesizare sau } \\
\text { contestație este anexată o copie } \\
\text { simplă, în format scris ori } \\
\text { electronic, după hotărârea comisiei } \\
\text { de etică care cuprinde și raportul } \\
\text { elaborat de către comisia de } \\
\text { analiză din cadrul unității sau } \\
\text { instituției în care presupusa } \\
\text { abatere s-a produs; }\end{array}$ \\
\hline
\end{tabular}

\section{B. Variantă aprobată de CEMU}

\begin{tabular}{|c|c|c|}
\hline $\begin{array}{l}\text { Art. } 309 \text { teza } 1 \text {, } \\
\text { LEN nr. } 1 / 2011\end{array}$ & $\begin{array}{l}\text { Articolul } 309 \\
\text { În urma unei sesizări, comisia de } \\
\text { etică universitară demarează } \\
\text { procedurile stabilite de Codul de } \\
\text { etică și deontologie universitară, } \\
\text { respectiv de Legea nr. } 206 / 2004, \text { cu } \\
\text { modificările și completările ulteri- } \\
\text { oare. Comisia răspunde autorului } \\
\text { sesizării în termen de } 30 \text { de zile de } \\
\text { la primirea sesizării și îi comunică } \\
\text { acestuia rezultatul procedurilor, } \\
\text { după încheierea acestora. }\end{array}$ & $\begin{array}{l}\text { Articolul } 309 \\
\text { În urma unei sesizări, comisia de } \\
\text { etică universitară demarează pro- } \\
\text { cedurile stabilite de prezenta lege, } \\
\text { de Codul de etică și deontologie } \\
\text { universitară, respectiv de Legea } \\
\text { nr. } 206 / 2004 \text {, cu modificările și } \\
\text { completările ulterioare. Comisia } \\
\text { răspunde autorului sesizării în } \\
\text { termen de } 30 \text { de zile de la primirea } \\
\text { sesizării și îi comunică acestuia } \\
\text { rezultatul procedurilor, după } \\
\text { încheierea acestora. }\end{array}$ \\
\hline $\begin{array}{l}\text { Art. } 309^{1} \text { teza } 1 \text {, } \\
\text { LEN nr. } 1 / 2011\end{array}$ & Introducere alineat nou & $\begin{array}{l}\text { Articolul 3091 } \\
\text { (1) La ședințele comisiei de etică } \\
\text { universitară, respectiv a comisiilor } \\
\text { de analiză, pot participa diferite } \\
\text { persoane în calitate de invitați, } \\
\text { printre care și consilierul juridic al } \\
\text { instituției. }\end{array}$ \\
\hline
\end{tabular}




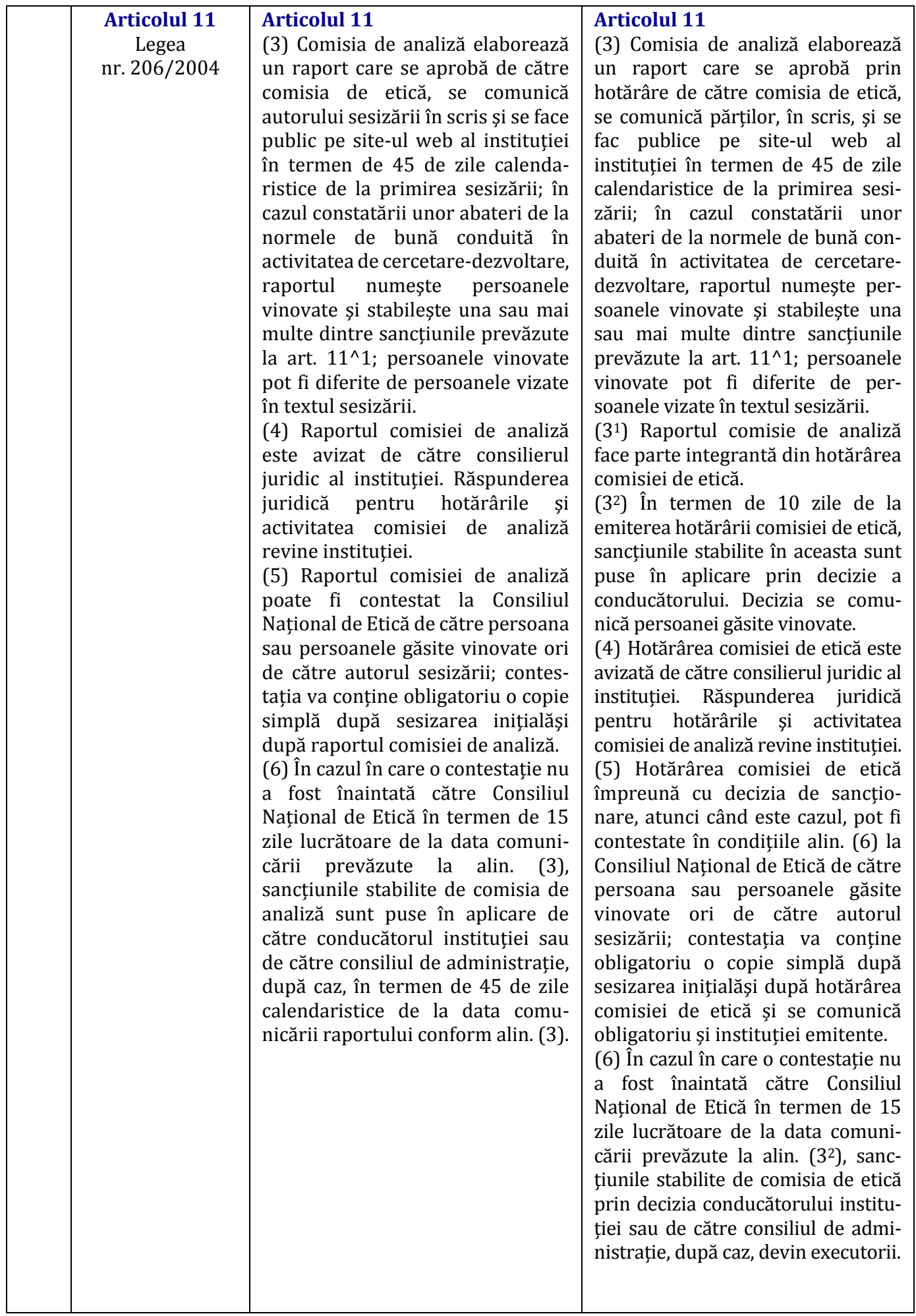




\begin{tabular}{|c|c|c|}
\hline $\begin{array}{c}\text { Articolul 21 } \\
\text { Regulamentul de } \\
\text { organizare și } \\
\text { funcționare al } \\
\text { CNECSDTI, } \\
\text { aprobat prin } \\
\text { Ordinul } 4655 \text { din } \\
2020\end{array}$ & $\begin{array}{l}\text { Articolul 21 } \\
\text { (1) CNECSDTI este obligat să } \\
\text { analizeze cazurile sesizate în } \\
\text { oricare dintre următoarele situații: } \\
\text { a) atunci când la sesizare sau } \\
\text { contestație este anexată o copie } \\
\text { simplă, în format scris ori } \\
\text { electronic, după raportul elaborat } \\
\text { de către comisia de analiză din } \\
\text { cadrul unității sau instituției în } \\
\text { care presupusa abatere s-a produs; }\end{array}$ & $\begin{array}{l}\text { Articolul 21 } \\
\text { (1) CNECSDTI este obligat să } \\
\text { analizeze cazurile sesizate în } \\
\text { oricare dintre următoarele situații: } \\
\text { a) atunci când la sesizare sau } \\
\text { contestație este anexată o copie } \\
\text { simplă, în format scris ori } \\
\text { electronic, după hotărârea comisiei } \\
\text { de etică care cuprinde și raportul } \\
\text { elaborat de către comisia de } \\
\text { analiză din cadrul unității sau } \\
\text { instituției în care presupusa } \\
\text { abatere s-a produs; }\end{array}$ \\
\hline
\end{tabular}

\section{$\underline{\text { Regimul juridic al documentelor comisiei de etică universitară }}$}

\section{MENTIIONĂM CĂ ACEASTĂ PROPUNERE, TRANSMISĂ CĂTRE CEMU NU SE REGĂSESTTE ÎN DOCUMENTUL PUBLIC PREZENTAT.}

Documentele emise de comisia de etică universitară, prin care se stabilesc sancțiuni, indiferent de terminologia actuală hotărâre/raport pot contestate în fața instanțelor de judecată. Lipsa unor prevederi exprese privind natura juridică a acestor acte, atât în LEN cât și în Legea nr. 206/2004, a generat o practică neunitară privind competența materială a instanțelor investite cu litigii având ca obiect contestarea acestor acte.

Astfel se disting diferite abordări, după cum urmează:

a) Stabilirea naturii juridice a hotărârilor comisiilor de etică, ca act administrativ, sens în care exemplificăm:

- Sentința civilă nr. 3295/2013 din 09 Sep. 2013, Trib. Constanța, contestație act administrativ fiscal (Contencios administrativ și fiscal);

- Sentința civilă nr. 4290/2013 din 12 nov. 2013, Trib. Constanța, anulare act administrativ (Contencios administrativ și fiscal);

- Sentința civilă nr. 4339/2013 pronunțată de Trib. București - Secția a IX-a Contencios Administrativ şi Fiscal în dosarul nr. XX;

- Sentința civilă nr. 6/2013 din 08 nov. 2013, C.A Galați, conflict de competență (Litigii de muncă);

- Decizie nr. 1003/2015 din 08 sep. 2015, C.A Timișoara, anulare act (Litigii de muncă);

- Sentința civilă nr. 351/2018 din 20 mar. 2018, Trib. Mureș, anulare act administrativ (Contencios administrativ și fiscal);

- Sentința civilă nr. 588/2018 din 19 apr. 2018, Trib. Constanța, anulare act administrativ (Contencios administrativ și fiscal).

b) Stabilirea naturii juridice a hotărârilor comisiilor de etică, ca act de dreptul muncii, sens în care exemplificăm:

- Sentința civilă nr. 10536/2013 din 29 nov. 2013, Trib. Argeș;

- Sentința civilă nr. 258/2016 Trib. Bistrița Năsăud; 
- Sentința civilă nr. 1904/2016 din 16 iun. 2016, Trib. Timiș, anulare act (Litigii de muncă);

- Sentința civilă nr. 6727/2017 din 12 dec. 2017, Trib. Cluj, contestație decizie de sancționare (Litigii de muncă);

- Decizie nr. 1428/2017 din 21 sep.2017, Curtea de Apel Brașov, contestație decizie de sancționare (Litigii de muncă);

- Sentința civilă nr. 2038/MAS/07.12.2017, pronunțată de Trib. Brașov;

- Decizie nr. 1524/2017 din 28 sep. 2017, Curtea de Apel Brașov, contestație decizie de sancționare (Litigii de muncă);

- Decizie nr. 753/2018 din 12 iun. 2018, Curtea de Apel Cluj, contestație decizie de sancționare (Litigii de muncă);

- Sentința civilă nr. 1793/2018 din 16 apr. 2018, Curtea de Apel București, conflict de competență (Contencios administrativ și fiscal) Decizie nr. 301/2019 din 21 ian. 2019, Trib. București, contestatie decizie de sanctionare (Litigii de muncă);

- Decizie nr. 27/2019 din 06 mar. 2019, Curtea de Apel Iași, anulare act administrativ (Contencios administrativ și fiscal).

c) Stabilirea naturii juridice a hotărârilor comisiilor de etică, ca act de dreptul muncii dar cu o procedură specială astfel cum instanța apreciază că „faptele sesizate nu au fost analizate de Comisia de Disciplină în cadrul unei cercetări disciplinare, ci de Comisia de Etică Universitară, într-o procedură distinctă, de analizare a încălcării unor norme privind etica universitară. În consecinţă, instanţa va analiza condiţiile de legalitate ale actelor emise de pârâtă prin prisma dispoziţiilor legale cuprinse în Titlul IV Capitolul II Sect a 8-a din Legea1/2011 - „Sancţiuni referitoare la încălcarea eticii universitare şi a bunei conduite în cercetare"- în art. 318-326 din Legea 1/2011 şi în regulamentele interne ale pârâtei", sens în care exemplificăm cu :

- Decizie nr. 6983/2018 din 02-oct-2018, Tribunalul București, drepturi bănești (Litigii de muncă)

- Decizie nr. 4873/2018 din 15-iun-2018, Tribunalul București, anulare act (Litigii de muncă)

Diferența de viziune în încadrarea actelor comisiei de etică în competența materială a instanțelor (Secțiile de dreptul muncii vs. Secțiile de contencios administrativ) a determinat nașterea conflictelor negative de competență. Nici în această situație încadrarea naturii juridice a actelor emise de comisia de etică universitară nu a fost unitară, regulatoarele de competență fiind de asemenea neunitare, sens în care exemplificăm cu:

- Sentința civilă nr. 3295/2013 din 09 sep. 2013, Trib. Constanța, contestație act administrativ fiscal (Contencios administrativ şi fiscal);

- Sentința civilă nr. 6/2013 din 08 nov. 2013, Curtea de Apel Galați, conflict de competență (Litigii de muncă);

- Sentința civilă nr. 587/2015 din 23 mar. 2015, Trib. Timiș, anulare act (Litigii de muncă); 
- Decizie nr. 2058/2017 din 06 dec. 2017, Curtea de Apel Brașov, contestație decizie de sancționare (Litigii de muncă);

- Sentința civilă nr. 565/2017 din 31 mar. 2017, Trib. Brașov, anulare act administrativ (Contencios administrativ și fiscal);

- Sentința civilă nr. 1793/2018 din 16 apr. 2018, Curtea de Apel București, conflict de competență (Contencios administrativ și fiscal);

- Sentința civilă nr. 351/2018 din 20 mar. 2018, Trib. Mureș, anulare act administrativ (Contencios administrativ și fiscal);

- Sentința civilă nr. 588/2018 din 19 apr. 2018, Trib. Constanța, anulare act administrativ (Contencios administrativ și fiscal).

Aspectelor mai sus menționate li se adaugă posibila interpretare ca fiind discriminatorie în cazul sancționării unui student atribuirea naturii juridice exclusiv de act administrativ (neavând contract individual de muncă) a hotărârii comisie de etică universitară de către instanțele de judecată, în baza aceleia și fapte (plagiatul în cazul lucrării de licență vs. plagiatul în cazul articolelor, cărților, cursurilor universitare, etc.).

Prevenirea discriminării și obținerea unei practici unitare a instanțelor de judecată se poate realiza prin modificarea art. 307 din LEN, astfel:

\begin{tabular}{|c|c|c|c|}
\hline 9. & $\begin{array}{c}\text { Art. 307, } \\
\text { LEN nr. } 1 / 2011\end{array}$ & $\begin{array}{l}\text { Articolul } \mathbf{3 0 7} \\
\text { Hotărârile comisiei de etică univer- } \\
\text { sitară sunt avizate de consilierul } \\
\text { juridic al universității. Răspun- } \\
\text { derea juridică pentru hotărârile și } \\
\text { activitatea comisiei de etică } \\
\text { universitară revine universității. }\end{array}$ & $\begin{array}{l}\text { Articolul } \mathbf{3 0 7} \\
\text { Hotărârile comisiei de etică univer- } \\
\text { sitară, acte administrativ-jurisdic- } \\
\text { ționale, sunt avizate de consilierul } \\
\text { juridic al universității. Răspun- } \\
\text { derea juridică pentru hotărârile și } \\
\text { activitatea comisiei de etică } \\
\text { universitară revine universității. }\end{array}$ \\
\hline
\end{tabular}

\section{$\underline{\text { Sancțiunile stabilite de către comisia de etică universitară }}$}

În ceea ce privește sancțiunile care se stabilesc de către Comisia de etică, o problemă deosebită o reprezintă sintagma „desfacere disciplinară a contractului de muncă” în art. 318 lit. (e) şi art. 324 lit. (g) din LEN care creează confuzie între răspunderea pentru încălcarea eticii universitare şi a bunei conduite în cercetare şi răspunderea disciplinară, chiar dacă procedura în acest ultim caz este derulată de către o comisie distinctă - comisia de cercetare disciplinară. Această confuzie este regăsită atât în unele regulamentele de organizare și funcționare a comisiilor de eticăa ${ }^{3}$, cât și în activitatea desfășurată de acestea ${ }^{4}$, și cu precădere în stabilirea competenței materiale a instanțelor de judecată, care este tratată neunitar, așa cum am arătat anterior.

\footnotetext{
${ }^{3}$ Spre exemplu: „acceptarea doar a sesizărilor care nu au depășit șase luni (prin raportare la termenul de prescripție aferent cercetării disciplinare, n.n.) de la săvârșirea abaterii de la codul de etică" - Raport ARACIS 1605/31.03.2020. ${ }^{4}$ Spre exemplu: Hotărârea 78 CEMU, în care se arată că „Membrii comisiei de etică a UTCN au considerat că domnul prof. univ. dr. ing. OAC are o activitate de cercetare științifică recunoscută, însă în privința activităților administrative și didactice contribuția dânsului este „nesatisfăcătoare” în cadrul Departamentului”; Raportul ARACIS, pentru Universitatea Apolonia din Iași, încheiat la data de 23.04.2019, unde sunt identificate următoarele situații: 1. pentru un număr de 3 cadre didactice care nu a putut justifica un număr de ore aferente pontajului lunii martie, soluția propusă de Comisia de Etică: neplata orelor trecute în mod eronat în pontajul aferent lunii; 2. pentru o situație conflictuală care a afectat
} 


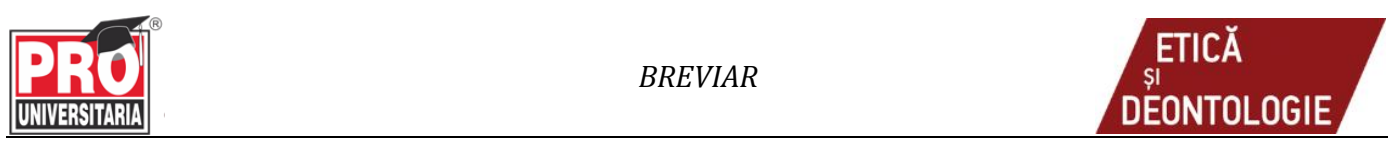

Deşi Legea nr. 206/2004 tratează exclusiv răspunderea personalului ce desfăşoară activități de cercetare-dezvoltare, folosirea sintagmei „desfacerea disciplinară a contractului de muncă" în art. 11^1 lit. (f) din Legea nr. 206/2004 creează în mod fals, prin corelare terminologică, prezumția unei răspunderi de tip disciplinar, ignorându-se în fapt procedura specifică a comisiei de etică şi natura juridică a actelor emise de acest organism decizional.

Comisia de etică universitară desfăşoară o procedură administrativ-judiciară atât cu privire la angajații din sistem, cât şi cu privire la studenții/doctoranzii din sistemul de învățământ. Pentru aceleași fapte care intră sub incidența Comisiei de etică universitară, chiar dacă din perspectiva raporturilor dintre persoanele mai sus identificate și instituțiile de învățământ superior, pentru personalul didactic şi de cercetare există un contract individual de muncă iar pentru studenți/studențiidoctoranzi un contract de școlarizare, prin hotărârea Comisiei de etică universitară nu se pot stabili sancțiuni disciplinare în cazul angajaţilor (art. 318 şi/sau art. 324 din LEN) şi sancțiuni de natură administrativă în cazul studenților ${ }^{5}$ ş istudențilordoctoranzi (art. 319 din LEN).

În vederea evitării confundării procedurii și sancțiunii aplicate de către Comisa de etică cu cele aplicate de Comisia de cercetare disciplinară, considerăm oportună, inclusiv sub aspect judiciar, ca terminologia folosită în legislație să fie în mod unitar: destituirea din funcție. Această terminologie este în concordanță cu prevederile LEN, Titlului IV Statutul personalului didactic, Capitolul II Statutul personalului didactic și de cercetare din învățământul superior, art. 285, care la alin. (1) reglementează funcțiile didactice, la alin. (2) reglementează funcțiile de cercetare iar la alin. (3) reglementează echivalența funcțiilor din cercetare cu funcțiile didactice. La art. 291 alin. (5) din LEN se arată că „prin personal didactic titular se înțelege personalul didactic care ocupă o funcție didactică într-o universitate", iar la alin. (7) că "funcțiilor de cercetare-dezvoltare din universități și personalului care le ocupă li se aplică prevederile Legii $n$ r. 319/2003 privind Statutul personalului de cercetare-dezvoltare."

\section{A. Formă transmisă de autoare către CEMU Propunere de modificare legislativă:}

- este necesară modificarea art. 318 lit. (e) din LEN şi modificarea art. 324 lit. (g) din LEN;

- este necesară modificarea art. 11^1 lit. (f) din Legea nr. 206/2004.

\footnotetext{
prestigiul Universității... prin faptul că doamna DP a solicitat examinarea fiicei sale, cu nerespectarea procedurile interne, folosind un limbaj neadecvat în conversațiile avute, soluția propusă de Comisia de Etică: faptele sesizate reprezintă o abatere disciplinară universitară și a propus Senatului universitar să desemneze o Comisie de disciplină.

${ }^{5}$ Decizie nr. 2295/2014 din 24 mar. 2014, Curtea de Apel București, anulare act administrativ (Contencios administrativ și fiscal): „Deși instanța de fond a reținut în mod corect că decizia de sancționare a reclamantului este un act administrativ complex, aceasta a omis faptul că motivarea măsurii de exmatriculare a reclamantului se face prin decizia de sancționare și este în sarcina compartimentului juridic al universității (art. 20 din Regulamentul de funcționare al Comisiei de Etică), decizie care este emisă de către decan sau rector (potrivit art. 21 din același regulament). Cum motivarea unui act administrativ este esențială și absolut necesară pentru aprecierea legalității respectivului act administrativ, rezultă că din actul administrativ complex, nu poate fi ignorată decizia de sancționare, care și în opinia pârâților, consemnată în încheierea de ședință din 20.09.2013, este act administrativ. Așa fiind o astfel de decizie este un act emis de o autoritate publică în executarea legii, actul stinge raporturi juridice, fiind actul care stinge raporturile dintre universitate și student, fiind astfel un act administrativ în înțelesul legii nr. 554/2004 (art. 2 lit c).”
} 


\begin{tabular}{|c|c|l|l|}
\hline $\begin{array}{c}\text { Nr. } \\
\text { crt. }\end{array}$ & \multicolumn{1}{|c|}{ Articol } & \multicolumn{1}{|c|}{ Text inițial } & \multicolumn{1}{c|}{ Text propus } \\
\hline 10. & $\begin{array}{c}\text { Art. 318 lit. (e) } \\
\text { LEN nr. 1/2011 }\end{array}$ & $\begin{array}{l}\text { Articolul 318 } \\
\text { e) desfacerea disciplinară a } \\
\text { contractului de muncă }\end{array}$ & $\begin{array}{l}\text { Articolul 318 } \\
\text { e) destituirea din funcție }\end{array}$ \\
\hline 11. & $\begin{array}{c}\text { Art. 324 lit. (g) } \\
\text { LEN nr. 1/2011 }\end{array}$ & $\begin{array}{l}\text { Articolul 324 } \\
\text { g) desfacerea disciplinară a } \\
\text { contractului de muncă }\end{array}$ & $\begin{array}{l}\text { Articolul 324 } \\
\text { g) destituirea din funcție }\end{array}$ \\
\hline 12. & $\begin{array}{c}\text { Art. 11^1 lit. (f) } \\
\text { din Legea } \\
\text { nr. 206/2004 }\end{array}$ & $\begin{array}{l}\text { Articolul 11^1 } \\
\text { f) desfacerea disciplinară a } \\
\text { contractului de muncă }\end{array}$ & $\begin{array}{l}\text { Articolul 11^1 } \\
\text { f) destituirea din funcție }\end{array}$ \\
\hline
\end{tabular}

\section{B. Formă aprobată de CEMU}

\begin{tabular}{|c|c|l|l|}
\hline $\begin{array}{c}\text { Nr. } \\
\text { crt. }\end{array}$ & Articol & \multicolumn{1}{|c|}{ Text inițial } & \multicolumn{1}{c|}{ Text propus } \\
\hline & $\begin{array}{c}\text { Art. 318 lit. (e) } \\
\text { LEN nr. 1/2011 }\end{array}$ & $\begin{array}{l}\text { Articolul 318 } \\
\text { e) desfacerea disciplinară a } \\
\text { contractului de muncă }\end{array}$ & $\begin{array}{l}\text { Articolul 318 } \\
\text { e) destituirea din funcția didactică } \\
\text { sau de cercetare }\end{array}$ \\
\hline & $\begin{array}{c}\text { Art. 324 lit. (g) } \\
\text { LEN nr. 1/2011 }\end{array}$ & $\begin{array}{l}\text { Articolul 324 } \\
\text { g) desfacerea disciplinară a } \\
\text { contractului de muncă }\end{array}$ & $\begin{array}{l}\text { Articolul 324 } \\
\text { g) destituirea din funcția didactică } \\
\text { sau de cercetare }\end{array}$ \\
\hline & $\begin{array}{c}\text { Art.11^1 lit. (f) } \\
\text { din Legea } \\
\text { nr. 206/2004 }\end{array}$ & $\begin{array}{l}\text { Articolul 11^1 } \\
\text { f) desfacerea disciplinară a } \\
\text { contractului de muncă }\end{array}$ & $\begin{array}{l}\text { Articolul 11^1 } \\
\text { f) destituirea din funcția didactică } \\
\text { sau de cercetare }\end{array}$ \\
\hline
\end{tabular}

\section{Termene de sesizare}

\section{MENTIIONĂM CĂ ACEASTĂ PROPUNERE, TRANSMISĂ CĂTRE CEMU NU SE REGĂSESTTE ÎN DOCUMENTUL PUBLIC PREZENTAT.}

Dreptul de a sesiza comisia de etică a unei instituție de învățământ superior cu privire la săvârșirea de către un membru al comunității academice a unei abateri de la normele de etică, aparține oricărei persoane fizice sau juridice (art. 11 alin. 1 din Legea nr. 206 din 2004), din universitate sau din afara universității (art. 308 alin. 1 din LEN). Însă nici una dintre aceste legi nu reglementează un termen de prescripție cu privire la depunerea unei sesizări.

Autonomia universitară a permis, prin intermediul reglementărilor interne ale instituțiilor de învățământ superior (coduri, regulamente de organizare și funcționare), introducerea unor astfel de termene de prescripție 6 .

Nici instanțele de judecată nu au o practică unitară în acest sens, acestea arătând fie că sesizările sunt imprescriptibile7, fie că sunt supuse unui termen de

\footnotetext{
${ }^{6}$ De exemplu: Hotărârea CEMU nr.61 - potrivit Codului de Etică al Universității din Petroșani, „CEU trebuie sesizată în termen de 30 de zile de la săvârşirea faptei considerată că reprezintă abatere de la prevederile Codului de etică”; Raportul ARACIS pentru Universitatea Dunărea de Jos, Galați, perioada vizitei 12-14.12.2018, în care se arată că „In Codul de etică și în Regulamentul de organizare și funcționare a comisiei sunt specificate ca termene de sesizare 30 de zile".

${ }^{7}$ Sentința civilă nr. 292/2012 din 01 oct. 2012, Curtea de Apel Oradea, Sentința nr. 351/2018 din 20 mar. 2018 , Tribunalul Mureș.
} 
prescripție de 6 luni prin asimilarea cu termenul de 6 luni de la sancționarea disciplinară conform Codului muncii ${ }^{8}$.

Deoarece atribuțiile Comisiilor de etică vizează două mari categorii de fapte contrare eticii este necesară realizarea unei distincții între acestea în ceea ce privește sesizarea/autosesizarea comisiilor:

Pentru faptele care vizează buna conduită în cercetarea științifică, dezvoltarea tehnologică şi inovare, cel puțin pentru respectarea drepturilor de autor sunt incidente și prevederile Legii nr. 8 din 1996 care impun termene de prescripție doar pentru protecția drepturilor patrimoniale de autor. Însă, pentru evitarea exercitării cu rea credință a dreptului de sesizare și evitarea stărilor de incertitudine, este necesară introducerea unui termen rezonabil pentru depunerea unei sesizări, termen care să curgă de la luarea la cunoștință de către autorul sesizării a săvârșirii faptei. Trebuie precizat că respingerea unei sesizări ca fiind tardiv introdusă de către un petent nu împiedică depunerea unei alte sesizări, cu același obiect, de către un alt petent, pentru care termenul de prescripție curge de la data de la care acesta din urmă a luat la cunoștință de săvârșirea faptei ilicite. Astfel sunt susținute prevederile HG 681 din 2011 privind aprobarea Codului studiilor universitare de doctorat și noile prevederi cuprinse în art. 1 ale Metodologiei referitoare la soluționarea sesizărilor cu privire la nerespectarea standardelor de calitate sau de etică profesională, inclusiv cu privire la existența plagiatului, în cadrul unei teze de doctorat, aprobată prin Ordinul 5229/2020.

Pentru faptele care vizează etica generală, aceste fapte fiind cu urmări imediate (jigniri, insulte, hărțuire, discriminare, ș.a.) și a căror cercetare presupune, de obicei, și audierea de martori, considerăm că poate fi impus un termen de prescripție mai scurt, care să curgă fie de la momentul săvârșirii faptei, pentru persoanele direct implicate sau lezate, fie de la momentul luării la cunoștință de săvârșirea faptei, pentru celelalte persoane.

Propunere de modificare legislativă: introducerea alin. (11) după art. 308 alin. (1) din LEN și respectiv după art. 11 alin. (1) din Legea nr. 206/2004.

\begin{tabular}{|c|c|l|l|}
\hline $\begin{array}{c}\text { Nr. } \\
\text { crt. }\end{array}$ & Articol & \multicolumn{1}{c|}{ Text inițial } & \multicolumn{1}{c|}{ Text propus } \\
\hline 13. & $\begin{array}{c}\text { Art. 308 alin. (1), } \\
\text { LEN nr. 1/2011 }\end{array}$ & $\begin{array}{l}\text { Articolul 308 } \\
\text { (1) Orice persoană, din universitate } \\
\text { sau din afara universității, poate } \\
\text { sesiza Comisiei de etică universitară } \\
\text { abateri săvârșite de membri ai ai } \\
\text { comunității universitare. }\end{array}$ & $\begin{array}{l}\text { Articolul 308 } \\
\text { (1) Orice persoană, din universitate } \\
\text { sau din afara universității, poate } \\
\text { sesiza Comisiei de etică universitară } \\
\text { abateri săvârșite de membri ai } \\
\text { comunității universitare. }\end{array}$ \\
\hline
\end{tabular}

\footnotetext{
${ }^{8}$ Sentința civilă nr. 258/2016 Tribunalul Bistrița Năsăud unde tribunalul reține că atâta timp cât o legislație specială nu prevede o procedură de sine stătătoare şi detailată, cu termene şi condiții de formă proprii, iar măsura dispusă afectează raporturile de muncă ale angajatului, procedura sancționării disciplinare trebuie îndeplinită cu respectarea prevederilor Codului muncii, în special a art. 252 alin. 1 şi 2, în termenele de 30 zile, respectiv 6 luni și cu emiterea unei decizii care să respecte condițiile de formă. În mod asemănător, Decizia nr. 301/2019 din 21 ian. 2019, Tribunalul București.
} 


\begin{tabular}{|c|c|c|c|}
\hline Nr. & Articol & Text inițial & Text propus \\
\hline & & & $\begin{array}{l}\text { (11) Pentru abaterile care intră sub } \\
\text { incidența Legii } 206 \text { din } 2004 \text { privind } \\
\text { buna conduită în cercetarea } \\
\text { ştiințifică, dezvoltarea tehnologică } \\
\text { şi inovare, termenul de prescripție } \\
\text { al depunerii unei sesizări este de } 1 \\
\text { an de la data la care autorul sesizării } \\
\text { a cunoscut săvârșirea abaterii. } \\
\text { Pentru celelalte abateri termenul } \\
\text { este de } 6 \text { luni de la data la care au } \\
\text { fost săvârșite, dacă autorul sesizării } \\
\text { este persoana vătămată, respectiv } \\
\text { de la data la care au fost cunoscute, } \\
\text { dacă autorul sesizării este o terță } \\
\text { persoană, dar fără a depăși un an de } \\
\text { la data săvârșirii. }\end{array}$ \\
\hline 14. & $\begin{array}{l}\text { Arti. 11 Legea } \\
\text { nr. 206/2004 }\end{array}$ & $\begin{array}{l}\text { Articolul 11 } \\
\text { (1) Procedurile pe care comisia de } \\
\text { etică, respectiv comisia de analiză } \\
\text { le desfăşoară în cazul sesizărilor } \\
\text { scrise, inițiate de persoane fizice } \\
\text { sau juridice cunoscute, ori în urma } \\
\text { autosesizării sunt detaliate în } \\
\text { Codul de etică, cu respectarea } \\
\text { prevederilor prezentei legi. }\end{array}$ & $\begin{array}{l}\text { Articolul 11 } \\
\text { (1) Procedurile pe care comisia de } \\
\text { etică, respectiv comisia de analiză } \\
\text { le desfăşoară în cazul sesizărilor } \\
\text { scrise, inițiate de persoane fizice } \\
\text { sau juridice cunoscute, ori în urma } \\
\text { autosesizării sunt detaliate în } \\
\text { Codul de etică, cu respectarea } \\
\text { prevederilor prezentei legi. } \\
\text { (11) Termenul de prescripție al } \\
\text { depunerii unei sesizări este de } 1 \text { an } \\
\text { de la data la care autorul sesizării a } \\
\text { cunoscut săvârșirea abaterii. }\end{array}$ \\
\hline
\end{tabular}

\section{Termene de solutionare}

Orice procedură de cercetare trebuie să fie supusă unor termene limitative, de decădere sau de prescripție. Pornind de la încadrarea diferită a naturii juridice a documentelor emise de comisia de etică universitară (act de dreptul muncii sau act de drept administrativ) practica instanțelor de judecată este neunitară cu privire la termenele asociate acestei proceduri.

Nici legiuitorul nu este consecvent cu privire la acest aspect, deoarece, cu privire la soluționarea sesizărilor/autosesizărilor depuse în fața comisiei de etică universitară se regăsesc următoarele prevederi:

- obligația comisiei de a răspunde autorului sesizării în termen de 30 de zile de la primirea sesizării și comunicarea acestuia rezultatul procedurilor, după încheierea acestora, (art. 309, teza a doua, din LEN). Această modalitate de exprimare a legiuitorului a condus la constatarea de către instanțele de judecată a faptului că ,în Legea $n r$. 1/2011 ... nu există nici o dispoziţie cu privire la perioada de timp în care poate fi efectuată cercetarea ... sau aplicată sancţiunea”,ceea ce „contravine atât principiilor care reglementează raporturile de muncă, cât şi principiilor legislaţiei civile, care 
prevede termene de prescripţie şi de decădere pentru marea majoritate a demersurilor juridice, imprescriptibilitatea existând doar în cazuri exprese şi limitate" (Sentința civilă nr. 258/2016 Tribunalul Bistrița Năsăud). Astfel, lipsa unui termen clar de soluționare a permis, prin coroborare cu identificarea unei sancțiuni identice - desfacerea disciplinară a contractului individual de muncă - atât pentru cercetarea în fața comisiei de etică universitară cât și în fața comisiei de disciplină, impunerea termenului de 30 de zile prevăzut de Codul muncii.

- obligația comisiei de a elabora un raport, care se aprobă de către comisia de etică și se comunică autorului sesizării ... în termen de 45 de zile calendaristice de la primirea sesizării (art. 11 alin. (3), teza 1 din Legea nr. 206/2004).

- având în vedere că în fața CNADTCU pot fi aduse în primă sesizare abaterile de la normele de etică cu privire la existența plagiatului în cadrul unei teze de doctorat, indiferent de data susținerii acesteia și de data acordării titlului de doctor, se deduce existența unui termen indirect, sub 30 de zile, de soluționare a cazului de către comisia de etică universitară. Acest termen deosebit de scurt este impus de prevederile art. 6 lit.e) coroborat cu art. 7 din Metodologia privind soluționarea sesizărilor cu privire la nerespectarea standardelor de calitate sau de etică profesională, inclusiv cu privire la existența plagiatului, în cadrul unei teze de doctorat, aprobată prin Ordinul 5229/2020, deoarece: (i) în vederea constituirii dosarului, secretariatul tehnic al CNATDCU solicită IOSUD/IOD să încarce în platformă, în format electronic, punctul de său vedere, fundamentat inclusiv pe hotărârea Comisiei de etică universitară, (ii) aceste documente se încarcă direct în platformă în termen de maximum 30 de zile de la data publicării deciziei privind admiterea sesizării spre analiză de către UEFISCDI și (iii) solicitarea secretariatul tehnic al CNATDCU către IOSUD/IOD se face în termen de maximum două zile de la admiterea sesizării spre analiză de către UEFISCDI. Neîncărcarea acestor documente în termen, pot fi considerate refuz, ceea ce constituie o încălcare a principiul răspunderii publice și duce la sancțiunile prevăzute de lege (art.11 din Metodologie).

În vederea evitării oricăror diferențe în ceea ce privește termenele de soluționare, respectiv pornind de la realitățile identificate în cadrul comisiilor de etică universitară, propunem ca termenul să fie de 45 de zile, în mod unitar.

Strâns legat de trecerea termenului de soluționare se află procedura comunicării. Legea prevede doar comunicarea către partea reclamantă, însă o importanță deosebită o are și comunicarea către partea reclamată/sancționată, deoarece de la acest moment curg termenele de contestare. Și în acest sens este necesară modificarea prevederilor art. 309.

\section{A. Formă trimisă de autoare către CEMU}

Propunere de modificare legislativă: Pentru claritatea prevederilor textul articolul 309 din LEN au fost aduse unele modificări/completări și a fost împărțit în două alineate. 


\begin{tabular}{|c|c|c|c|}
\hline $\begin{array}{l}\text { Nr. } \\
\text { crt. }\end{array}$ & Articol & Text inițial & Text propus \\
\hline 15. & $\begin{array}{c}\text { Art. 309, LEN nr. } \\
1 / 2011\end{array}$ & $\begin{array}{l}\text { Articolul } 309 \\
\text { În urma unei sesizări, comisia de } \\
\text { etică universitară demarează pro- } \\
\text { cedurile stabilite de Codul de etică și } \\
\text { deontologie universitară, respectiv } \\
\text { de Legea nr. } 206 / 2004 \text {, cu modifi- } \\
\text { cările și completările ulterioare. } \\
\text { Comisia răspunde autorului } \\
\text { sesizării în termen de } 30 \text { de zile de } \\
\text { la primirea sesizării și îi comunică } \\
\text { acestuia rezultatul procedurilor, } \\
\text { după încheierea acestora. }\end{array}$ & $\begin{array}{l}\text { (1) În urma unei sesizări, comisia } \\
\text { de etică universitară demarează } \\
\text { procedurile stabilite de Codul de } \\
\text { etică și deontologie universitară, } \\
\text { respectiv de Legea nr. 206/2004, } \\
\text { cu modificările și completările } \\
\text { ulterioare. } \\
\text { (2) Comisia răspunde autorului } \\
\text { sesizării, soluționează și comunică } \\
\text { hotărârea părților în termen de } 45 \\
\text { de zile calendaristice de la primirea } \\
\text { sesizării. }\end{array}$ \\
\hline
\end{tabular}

\section{B. Formă aprobată de CEMU}

\begin{tabular}{|c|c|c|c|}
\hline $\begin{array}{l}\text { Nr. } \\
\text { crt. }\end{array}$ & Articol & Text inițial & Text propus \\
\hline & $\begin{array}{c}\text { Art. 309, LEN nr. } \\
1 / 2011\end{array}$ & $\begin{array}{l}\text { Articolul } 309 \\
\text { În urma unei sesizări, comisia de } \\
\text { etică universitară demarează pro- } \\
\text { cedurile stabilite de Codul de etică și } \\
\text { deontologie universitară, respectiv } \\
\text { de Legea nr. } 206 / 2004 \text {, cu modifi- } \\
\text { cările și completările ulterioare. } \\
\text { Comisia răspunde autorului } \\
\text { sesizării în termen de } 30 \text { de zile de } \\
\text { la primirea sesizării și îi comunică } \\
\text { acestuia rezultatul procedurilor, } \\
\text { după încheierea acestora. }\end{array}$ & $\begin{array}{l}\text { (1) În urma unei sesizări, comisia de } \\
\text { etică universitară demarează proce- } \\
\text { durile stabilite de Codul de etică și } \\
\text { deontologie universitară, respectiv } \\
\text { de Legea nr. 206/2004, cu modifi- } \\
\text { cările și completările ulterioare. } \\
\text { Comisia răspunde autorului sesi- } \\
\text { zării în termen de } 30 \text { de zile de la } \\
\text { primirea sesizării și îi comunică } \\
\text { acestuia rezultatul procedurilor, } \\
\text { după încheierea acestora. } \\
\text { (2) Comisia răspunde autorului } \\
\text { sesizării, soluționează și comunică } \\
\text { hotărârea părților în termen de } 45 \\
\text { de zile calendaristice de la primirea } \\
\text { sesizării . }\end{array}$ \\
\hline
\end{tabular}

Propunere de modificare legislativă a art. 6 lit. e) din Metodologia privind soluționarea sesizărilor cu privire la nerespectarea standardelor de calitate sau de etică profesională, inclusiv cu privire la existența plagiatului, în cadrul unei teze de doctorat, aprobată prin Ordinul 5229/2020.

Deoarece:

- punctul de vedere al IOSUD/IOD este consultativ iar dacă acesta nu este transmis în termen de maximum 30 de zile de la data publicării deciziei privind admiterea sesizării pe site-ul www.cnatdcu.ro, procesul de analiză a sesizării continuă la nivelul Consiliului general conform prevederilor prezentei metodologii,

- în situația în care în fața CNACDTU este adusă pentru prima dată sesizarea cu privire la abaterea de la normele de etică, acesta se pronunță și asupra existenței plagiatului,

- solicitarea expresă ca pentru aceeași cauză să se pronunțe și comisia de etică universitară poate constitui dublă sancționare, 


\section{Propunere transmisă și aprobată de CEMU}

\begin{tabular}{|c|c|c|c|}
\hline $\begin{array}{l}\text { Nr. } \\
\text { crt. }\end{array}$ & Articol & Text inițial & Text propus \\
\hline 16. & $\begin{array}{l}\text { Art. } 6 \text { lit. e) din } \\
\text { Metodologia } \\
\text { privind soluționa- } \\
\text { rea sesizărilor cu } \\
\text { privire la neres- } \\
\text { pectarea standar- } \\
\text { delor de calitate } \\
\text { sau de etică pro- } \\
\text { fesională, inclusiv } \\
\text { cu privire la exis- } \\
\text { tența plagiatului, } \\
\text { în cadrul unei teze } \\
\text { de doctorat, apro- } \\
\text { bată prin Ordinul } \\
5229 / 2020\end{array}$ & $\begin{array}{l}\text { Articolul } 6 \\
\text { e) punctul de vedere al IOSUD/ } \\
\text { IOD, care este consultativ și se } \\
\text { referă la propunerea de menținere/ } \\
\text { retragere a titlului de doctor, } \\
\text { semnată de rector sau, după caz, de } \\
\text { președintele Academiei Române, } \\
\text { documentele și reglementările } \\
\text { interne, în vigoare la data înmatri- } \\
\text { culării la doctorat a autorului tezei } \\
\text { de doctorat și aplicabile la data } \\
\text { susținerii publice, care au funda- } \\
\text { mentat această propunere, în } \\
\text { principal hotărârea Comisiei de } \\
\text { etică universitară, avizată juridic, } \\
\text { și la alte măsuri interne stabilite în } \\
\text { cazul în care s-a constatat } \\
\text { încălcarea eticii universitare; }\end{array}$ & $\begin{array}{l}\text { Articolul } 6 \\
\text { e) punctul de vedere al IOSUD/ } \\
\text { IOD, care este consultativ și se } \\
\text { referă la propunerea de menținere/ } \\
\text { retragere a titlului de doctor, } \\
\text { semnată de rector sau, după caz, de } \\
\text { președintele Academiei Române, } \\
\text { documentele și reglementările } \\
\text { interne, în vigoare la data înmatri- } \\
\text { culării la doctorat a autorului tezei } \\
\text { de doctorat și aplicabile la data } \\
\text { susținerii publice, care au funda- } \\
\text { mentat această propunere, exis- } \\
\text { tența unei hotărâri a Comisiei de } \\
\text { etică universitară, avizată juridic, și } \\
\text { la alte măsuri interne stabilite în } \\
\text { cazul în care s-a constatat încălca- } \\
\text { rea eticii universitare; }\end{array}$ \\
\hline
\end{tabular}

\section{Punerea în aplicare a documentelor comisiei de etică universitară}

\section{LEN prevede că sancțiunile stabilite de comisia de etică și deontologie} universitară sunt puse în aplicare de către decan sau rector, după caz, în termen de 30 de zile de la stabilirea lor (art. 322).

Tot LEN prevede la art. 326 că sancțiunile stabilite de CNECSDTI sunt puse în aplicare în termen de 30 de zile de la data emiterii hotărârii, după caz, de (...) conducătorii instituțiilor de învățământ superior sau ai unităților de cercetaredezvoltare. Conform art. 207 alin. (2) lit. (a) şi art. 213 alin. (6) LEN rectorul este conducătorul şi reprezentantul legal al universității.

Pentru sancțiunile aplicate în baza Legii 206 din 2004, art. 11 alin.(6) din această lege, prevede că sancțiunile stabilite de comisia de analiză (din cadrul comisiei de etică n.n.) sunt puse în aplicare de către conducătorul instituției sau de către consiliul de administrație, după caz, în termen de 45 de zile calendaristice de la data comunicării raportului conform alin. (3).

Propunere de modificare legislativă: Pentru uniformizarea prevederilor propunem următoarea modificare legislativă a art.322 LEN:

\section{Propunere transmisă si aprobată de CEMU}

\begin{tabular}{|c|c|c|c|}
\hline 17. & $\begin{array}{c}\text { Art. } 322 \\
\text { Legea } 1 / 2011\end{array}$ & $\begin{array}{l}\text { Articolul } 322 \\
\text { Sancțiunile stabilite de comisia de } \\
\text { etică și deontologie universitară } \\
\text { sunt puse în aplicare de către decan } \\
\text { sau rector, după caz, în termen de } 30 \\
\text { de zile de la stabilirea sanctiunilor. }\end{array}$ & $\begin{array}{l}\text { Articolul } 322 \\
\text { Sancțiunile stabilite de comisia de } \\
\text { etică și deontologie universitară } \\
\text { sunt puse în aplicare de către rector, } \\
\text { după caz, în termen de } 30 \text { de zile de } \\
\text { la stabilirea sancțiunilor. }\end{array}$ \\
\hline
\end{tabular}




\section{Denumirea comisiei de etică universitară}

Legea nr. 1. din 2011 a educației naționale este inconsecventă cu denumirea documentului în baza căruia comisiile de etică universitare stabilesc existența faptelor ce încalcă normele de etică și deontologie universitară, de bună conduită în cercetarea ştiințifică, dezvoltarea tehnologică şi inovare.

Pentru același document, se întâlnesc următoarele denumiri astfel:

- Senatul aprobă și Carta conține Codul de etică și deontologie profesională universitară;

- Răspunderea publică obligă la respectarea Codului de etică și deontologie profesională;

- Studenții trebuie să respecte și sunt sancționați după Codului de etică și deontologie universitară;

- Personalul din învățământul superior are drepturi și îndatoriri din Codul de etică universitară.

Propunere de modificare legislativă: armonizarea denumirii sub forma Codul de etică și deontologie universitară, care v-a duce și la armonizarea denumirii comisiei.

Propunere transmisă și aprobată de CEMU

\begin{tabular}{|c|c|c|c|}
\hline $\begin{array}{l}\text { Nr. } \\
\text { crt. }\end{array}$ & Articol & Text inițial & Text propus \\
\hline 18. & $\begin{array}{c}\text { Art. } 124 \text {, alin. (1), } \\
\text { lit. c), } \\
\text { LEN nr. } 1 / 2011\end{array}$ & $\begin{array}{l}\text { Articolul 124 } \\
\text { (1) Răspunderea publică obligă } \\
\text { orice instituție de învățământ } \\
\text { superior, de stat sau particulară: } \\
\text { c) să respecte politicile de echitate } \\
\text { și etică universitară, cuprinse în } \\
\text { Codul de etică și deontologie } \\
\text { profesională aprobat de senatul } \\
\text { universitar; }\end{array}$ & $\begin{array}{l}\text { Articolul 124 } \\
\text { (1) Răspunderea publică obligă } \\
\text { orice instituție de învățământ } \\
\text { superior, de stat sau particulară: } \\
\text { c) să respecte politicile de echitate } \\
\text { și etică universitară, cuprinse în } \\
\text { Codul de etică și deontologie } \\
\text { universitară aprobat de senatul } \\
\text { universitar; }\end{array}$ \\
\hline 19. & $\begin{array}{l}\text { Art. 128, alin. (2), } \\
\text { lit. b), } \\
\text { LEN nr. } 1 / 2011\end{array}$ & $\begin{array}{l}\text { Articolul } 128 \\
\text { (2) Carta universitară se referă, în } \\
\text { mod obligatoriu, cel puțin la: } \\
\text { b) Codul de etică și deontologie } \\
\text { profesională universitară; }\end{array}$ & $\begin{array}{l}\text { Articolul } 128 \\
\text { (2) Carta universitară se referă, în } \\
\text { mod obligatoriu, cel puțin la: } \\
\text { b) Codul de etică și deontologie } \\
\text { universitară; }\end{array}$ \\
\hline 20. & $\begin{array}{l}\text { Art. 130, alin. (1), } \\
\text { prima teză, } \\
\text { LEN nr. } 1 / 2011\end{array}$ & $\begin{array}{l}\text { Articolul 130 } \\
\text { (1) Instituțiile de învățământ } \\
\text { superior adoptă un cod de etică } \\
\text { și deontologie profesională } \\
\text { universitară. Acesta face parte } \\
\text { din Carta universitară și include } \\
\text { obligatoriu: .... }\end{array}$ & $\begin{array}{l}\text { Articolul 130 } \\
\text { (1) Instituțiile de învățământ } \\
\text { superior adoptă un cod de etică } \\
\text { si deontologie universitară. } \\
\text { Acesta face parte din Carta uni- } \\
\text { versitară și include obligatoriu: .... }\end{array}$ \\
\hline 21. & $\begin{array}{l}\text { Art. 213, alin. (2) } \\
\text { și (14), } \\
\text { LEN nr. } 1 / 2011\end{array}$ & $\begin{array}{l}\text { Articolul } 213 \\
\text { (2) Atribuțiile senatului universi- } \\
\text { tar sunt următoarele: } \\
\text { f) elaborează și aprobă Codul de } \\
\text { asigurare a calității și Codul de }\end{array}$ & $\begin{array}{l}\text { Articolul } 213 \\
\text { (2) Atribuțiile senatului universi- } \\
\text { tar sunt următoarele: } \\
\text { f) elaborează și aprobă Codul de } \\
\text { asigurare a calității și Codul de } \\
\text { etică și deontologie universitară; }\end{array}$ \\
\hline
\end{tabular}




\begin{tabular}{|c|c|c|c|}
\hline $\begin{array}{l}\text { Nr. } \\
\text { crt. }\end{array}$ & Articol & Text inițial & Text propus \\
\hline & & $\begin{array}{l}\text { etică și deontologie profesio- } \\
\text { nală universitară; } \\
\text {... } \\
\text { (14) Studenții au cel puțin un } \\
\text { reprezentant în comisiile de } \\
\text { etică, de cazări, de asigurare a } \\
\text { calității, precum și în alte comisii } \\
\text { cu caracter social. }\end{array}$ & $\begin{array}{l}\text {... } \\
\text { (14) Studenții au cel puțin un } \\
\text { reprezentant în comisiile de } \\
\text { etică și deontologie universi- } \\
\text { tară, de cazări, de asigurare a } \\
\text { calității, precum și în alte comisii } \\
\text { cu caracter social. }\end{array}$ \\
\hline 22. & $\begin{array}{l}\text { Art. 304, alin. (1), } \\
\text { LEN nr. 1/2011 }\end{array}$ & $\begin{array}{l}\text { Articolul 304 } \\
\text { (1) Personalul din învățământul } \\
\text { superior are drepturi și îndatoriri } \\
\text { care decurg din Carta universi- } \\
\text { tară, din Codul de etică univer- } \\
\text { sitară, din contractul individual } \\
\text { de muncă, precum și din legislația } \\
\text { în vigoare. }\end{array}$ & $\begin{array}{l}\text { Articolul 304 } \\
\text { (1) Personalul din învătământul } \\
\text { superior are drepturi și îndatoriri } \\
\text { care decurg din Carta univer- } \\
\text { sitară, din Codul de etică și } \\
\text { deontologie universitară, din } \\
\text { contractul individual de muncă, } \\
\text { precum și din legislația în vigoare. }\end{array}$ \\
\hline 23. & $\begin{array}{l}\text { Art. } 308 \text { alin. (1), } \\
\text { LEN nr. 1/2011 }\end{array}$ & $\begin{array}{l}\text { Articolul } \mathbf{3 0 8} \\
\text { (1) Orice persoană, din univer- } \\
\text { sitate sau din afara universității, } \\
\text { poate sesiza Comisiei de etică } \\
\text { universitară abateri săvârșite de } \\
\text { membri ai comunității } \\
\text { universitare. }\end{array}$ & $\begin{array}{l}\text { Articolul } \mathbf{3 0 8} \\
\text { (1) Orice persoană, din univer- } \\
\text { sitate sau din afara universității, } \\
\text { poate sesiza Comisiei de etică și } \\
\text { deontologie universitară abateri } \\
\text { săvârșite de membri ai comunității } \\
\text { universitare. }\end{array}$ \\
\hline 24. & $\begin{array}{c}\text { Art. 321, } \\
\text { LEN nr. 1/2011 }\end{array}$ & $\begin{array}{l}\text { Articolul } 321 \\
\text { În cazul abaterilor de la buna } \\
\text { conduită în cercetarea științifică, } \\
\text { comisia de etică universitară } \\
\text { stabilește, conform Legii nr. 206/ } \\
2004 \text {, cu modificările și comple- } \\
\text { tările ulterioare, Codului de etică și } \\
\text { deontologie profesională al perso- } \\
\text { nalului de cercetare-dezvoltare și } \\
\text { Codului de etică și deontologie } \\
\text { profesională. }\end{array}$ & $\begin{array}{l}\text { Articolul } 321 \\
\text { În cazul abaterilor de la buna } \\
\text { conduită în cercetarea științifică, } \\
\text { comisia de etică și deontologie } \\
\text { universitară stabilește, conform } \\
\text { Legii nr. 206/2004, cu modifi- } \\
\text { cările și completările ulterioare, } \\
\text { Codului de etică și deontologie } \\
\text { profesională al personalului de } \\
\text { cercetare-dezvoltare și Codului } \\
\text { de etică și deontologie } \\
\text { profesională. }\end{array}$ \\
\hline
\end{tabular}


TABEL FINAL

FORMA FINALĂ A PROPUNERILOR DE MODIFICARE LEGISLATIVĂ

\section{FORMA FINALĂ A PROPUNERILOR DE MODIFICARE A ARTICOLELOR CUPRINSE ÎN LEN nr.1/2011}

Forma finală propusă pentru articolele:

Art. 124, alin. (1), lit.c); Art. 128, alin. (2), lit.b); Art. 130, alin. (1), prima teză; Art. 213, alin. (2) și (14); Art. 304, alin. (1) din LEN nr. 1/2011

\begin{tabular}{|c|c|c|c|}
\hline $\begin{array}{l}\text { Nr. } \\
\text { crt. }\end{array}$ & Articol & Text inițial & Text propus \\
\hline 18. & $\begin{array}{l}\text { Art. } 124 \text {, alin. (1), } \\
\text { lit. c), } \\
\text { LEN nr. } 1 / 2011\end{array}$ & $\begin{array}{l}\text { Articolul } 124 \\
\text { (1) Răspunderea publică obligă } \\
\text { orice instituție de învățământ } \\
\text { superior, de stat sau particulară: } \\
\text { c) să respecte politicile de echitate } \\
\text { și etică universitară, cuprinse în } \\
\text { Codul de etică și deontologie } \\
\text { profesională aprobat de senatul } \\
\text { universitar; }\end{array}$ & $\begin{array}{l}\text { Articolul } 124 \\
\text { (1) Răspunderea publică obligăă } \\
\text { orice instituție de învățământ } \\
\text { superior, de stat sau particulară: } \\
\text { c) să respecte politicile de echitate } \\
\text { și etică universitară, cuprinse în } \\
\text { Codul de etică și deontologie } \\
\text { universitară aprobat de senatul } \\
\text { universitar; }\end{array}$ \\
\hline 19. & $\begin{array}{l}\text { Art. 128, alin. (2), } \\
\text { lit. b), } \\
\text { LEN nr. } 1 / 2011\end{array}$ & $\begin{array}{l}\text { Articolul } 128 \\
\text { (2) Carta universitară se referă, în } \\
\text { mod obligatoriu, cel puțin la: } \\
\text { b) Codul de etică și deontologie } \\
\text { profesională universitară; }\end{array}$ & $\begin{array}{l}\text { Articolul } 128 \\
\text { (2) Carta universitară se referă, în } \\
\text { mod obligatoriu, cel puțin la: } \\
\text { b) Codul de etică și deontologie } \\
\text { universitară; }\end{array}$ \\
\hline 20. & $\begin{array}{l}\text { Art. 130, alin. (1), } \\
\text { prima teză, } \\
\text { LEN nr. } 1 / 2011\end{array}$ & $\begin{array}{l}\text { Articolul 130 } \\
\text { (1) Instituțiile de învățământ } \\
\text { superior adoptă un cod de etică și } \\
\text { deontologie profesională uni- } \\
\text { versitară. Acesta face parte din } \\
\text { Carta universitară și include } \\
\text { obligatoriu:.... }\end{array}$ & $\begin{array}{l}\text { Articolul } 130 \\
\text { (1) Instituțiile de învățământ } \\
\text { superior adoptă un cod de etică și } \\
\text { deontologie universitară. Acesta } \\
\text { face parte din Carta universitară și } \\
\text { include obligatoriu: .... }\end{array}$ \\
\hline 21. & $\begin{array}{l}\text { Art. } 213 \text {, alin. (2) } \\
\text { și }(14) \\
\text { LEN nr. } 1 / 2011\end{array}$ & $\begin{array}{l}\text { Articolul } 213 \\
\text { (2) Atribuțiile senatului universitar } \\
\text { sunt următoarele: } \\
\text { f) elaborează și aprobă Codul de } \\
\text { asigurare a calității și Codul de } \\
\text { etică și deontologie profesională } \\
\text { universitară; } \\
\ldots \\
\text { (14) Studenții au cel puțin un } \\
\text { reprezentant în comisiile de etică, } \\
\text { de cazări, de asigurare a calității, } \\
\text { precum și în alte comisii cu } \\
\text { caracter social. }\end{array}$ & $\begin{array}{l}\text { Articolul } 213 \\
\text { (2) Atribuțiile senatului universitar } \\
\text { sunt următoarele: } \\
\text { f) elaborează și aprobă Codul de } \\
\text { asigurare a calității și Codul de } \\
\text { etică și deontologie universitară; } \\
\text {... } \\
\text { (14) Studenții au cel puțin un } \\
\text { reprezentant în comisiile de etică } \\
\text { și deontologie universitară, de } \\
\text { cazări, de asigurare a calității, } \\
\text { precum și în alte comisii cu } \\
\text { caracter social. }\end{array}$ \\
\hline 22. & $\begin{array}{l}\text { Art. 304, alin. (1), } \\
\text { LEN nr. 1/2011 }\end{array}$ & $\begin{array}{l}\text { Articolul 304 } \\
\text { (1) Personalul din învățământul } \\
\text { superior are drepturi și îndatoriri }\end{array}$ & $\begin{array}{l}\text { Articolul 304 } \\
\text { (1) Personalul din învățământul } \\
\text { superior are drepturi și îndatoriri }\end{array}$ \\
\hline
\end{tabular}




\begin{tabular}{|c|c|c|l|}
\hline $\begin{array}{l}\text { Nr. } \\
\text { crt. }\end{array}$ & Articol & \multicolumn{1}{|c|}{ Text inițial } & \multicolumn{1}{c|}{ Text propus } \\
\hline & & $\begin{array}{l}\text { care decurg din Carta universitară, } \\
\text { din Codul de etică universitară, } \\
\text { din contractul individual de muncă, } \\
\text { precum și din legislația în vigoare. }\end{array}$ & $\begin{array}{l}\text { care decurg din Carta universitară, } \\
\text { din Codul de etică și deontologie } \\
\text { universitară, din contractul } \\
\text { individual de muncă, precum și din } \\
\text { legislația în vigoare. }\end{array}$ \\
\hline
\end{tabular}

Forma finală propusă pentru articolul 306 LEN, prin cumularea modificărilor de la nr. crt. 1, 3 și 4:

\begin{tabular}{|c|c|c|c|}
\hline $\begin{array}{l}\text { Nr. } \\
\text { crt. }\end{array}$ & Articol & Text inițial & Text propus \\
\hline $\begin{array}{l}\text { 1. } \\
\text { și } \\
3 . \\
\text { și } \\
4 .\end{array}$ & $\begin{array}{c}\text { Art. } 306 \\
\text { LEN nr. } 1 / 2011\end{array}$ & $\begin{array}{l}\text { Articolul 306 } \\
\text { (1) La nivelul fiecărei universități } \\
\text { funcționează comisia de etică } \\
\text { universitară. } \\
\text { (2) Structura și componența } \\
\text { comisiei de etică universitară este } \\
\text { propusă de consiliul de adminis- } \\
\text { trație, avizată de senatul universitar } \\
\text { și aprobată de rector. Membrii } \\
\text { comisiei sunt persoane cu prestigiu } \\
\text { profesional și autoritate morală. Nu } \\
\text { pot fi membri ai comisiei de etică } \\
\text { universitară persoanele care ocupă } \\
\text { vreuna dintre funcțiile: rector, } \\
\text { prorector, decan, prodecan, director } \\
\text { administrativ, director de departa- } \\
\text { ment sau de unitate de cercetare- } \\
\text { dezvoltare, proiectare, micropro- } \\
\text { ducție. } \\
\text { (3) Comisia de etică universitară } \\
\text { are următoarele atribuții: } \\
\text { a) analizează și soluționează } \\
\text { abaterile de la etica universitară, pe } \\
\text { baza sesizărilor sau prin } \\
\text { autosesizare, conform Codului de } \\
\text { etică și deontologie universitară; } \\
\text {--- alte atribuții prevăzute de } \\
\text { e) alte } \\
\text { prezenta lege sau stabilite conform } \\
\text { Cartei universitare, conform legii. }\end{array}$ & $\begin{array}{l}\text { Articolul } 306 \\
\text { (1) La nivelul fiecărei universități } \\
\text { funcționează comisia de etică } \\
\text { universitară, organism decizional, } \\
\text { independent, pe lângă Senatul } \\
\text { universitar. Nerespectarea inde- } \\
\text { pendenței CEU în activitatea sa } \\
\text { constituie încălcare a art. } 124 \text { alin. } \\
\text { (1) lit. a). } \\
\text { (11) Mandatul comisiei este de } 4 \text { ani. } \\
\text { (2) Structura și componența } \\
\text { comisiei de etică universitară este } \\
\text { propusă de consiliul de adminis- } \\
\text { trație, avizată de senatul universitar } \\
\text { și numită de rector, cu respectarea } \\
\text { prevederilor art. } 213 \text { alin. (14). } \\
\text { (21) Membrii comisiei sunt } \\
\text { persoane cu prestigiu profesional și } \\
\text { autoritate morală. Nu pot fi membri } \\
\text { ai comisiei de etică universitară } \\
\text { persoanele care ocupă vreuna } \\
\text { dintre funcțile: rector, prorector, } \\
\text { decan, prodecan, director admi- } \\
\text { nistrativ, director de departament } \\
\text { sau de unitate de cercetare-dez- } \\
\text { voltare, proiectare, microproducție. } \\
\text { În situația nefinalizării procedurilor } \\
\text { prevăzute de art. 203 alin. (2) } \\
\text { pentru desemnarea reprezentan- } \\
\text { tului studenților în comisia de etică, } \\
\text { reprezentantul studenților în } \\
\text { consiliul de administrație devine de } \\
\text { drept membru al comisiei de etică, } \\
\text { până la finalizarea procedurilor de } \\
\text { desemnare. } \\
\text { (3) Comisia de etică universitarăă } \\
\text { are următoarele atribuții: } \\
\text { a) numește comisii de analiză } \\
\text { pentru examinarea sesizărilor } \\
\text { referitoare la abaterile de la etica } \\
\text { universitară, pe baza sesizărilor }\end{array}$ \\
\hline
\end{tabular}




\begin{tabular}{|c|c|c|c|}
\hline $\begin{array}{l}\text { Nr. } \\
\text { crt. }\end{array}$ & Articol & Text inițial & Text propus \\
\hline & & & $\begin{array}{l}\text { sau prin autosesizare, conform } \\
\text { Codului de etică și deontologie } \\
\text { universitară; } \\
\text { a') soluționează abaterile de la etica } \\
\text { universitară prin emiterea unei } \\
\text { hotărâri în baza raportului comisiei } \\
\text { de analiză. Raportul comisie de } \\
\text { analiză face parte integrantă din } \\
\text { hotărârea comisiei de etică. } \\
\text {--- alte atribuții prevăzute de lege } \\
\text { e) alte } \\
\text { sau stabilite conform Cartei } \\
\text { universitare, conform legii. }\end{array}$ \\
\hline
\end{tabular}

Forma finală propusă pentru articolului 307 LEN

\begin{tabular}{|l|l|l|l|}
\hline $\begin{array}{c}\text { Nr. } \\
\text { crt. }\end{array}$ & \multicolumn{1}{|c|}{ Articol } & \multicolumn{1}{c|}{ Text inițial } & \multicolumn{1}{c|}{ Text propus } \\
\hline & & $\begin{array}{l}\text { Articolul 307 } \\
\text { Hotărârile comisiei de etică univer- } \\
\text { sitară sunt avizate de consilierul } \\
\text { juridic al universității. Răspunderea } \\
\text { juridică pentru hotărârile și active- } \\
\text { tatea comisiei de etică universitară } \\
\text { revine universității. }\end{array}$ & $\begin{array}{l}\text { Articolul 307 } \\
\text { Hotărârile comisiei de etică univer- } \\
\text { sitară, acte administrativ-jurisdic- } \\
\text { ționale, sunt avizate de consilierul } \\
\text { juridic al universității. Răspun- } \\
\text { derea juridică pentru hotărârile și } \\
\text { activitatea comisiei de etică } \\
\text { universitară revine universității. }\end{array}$ \\
\hline & $\begin{array}{l}\text { Art. 307, LEN nr. } \\
1 / 2011\end{array}$ & &
\end{tabular}

Forma finală propusă pentru articolul 308 alin. (1) LEN, prin cumularea modificărilor de la nr. crt. 13 și 23.

\begin{tabular}{|c|c|c|c|}
\hline $\begin{array}{l}\text { Nr. } \\
\text { crt. }\end{array}$ & Articol & Text inițial & Text propus \\
\hline $\begin{array}{c}13 . \\
\text { și } \\
23 .\end{array}$ & $\begin{array}{l}\text { Art. } 308 \text { alin. (1), } \\
\text { LEN nr. } 1 / 2011\end{array}$ & $\begin{array}{l}\text { Articolul } \mathbf{3 0 8} \\
\text { (1) Orice persoană, din universitate } \\
\text { sau din afara universității, poate } \\
\text { sesiza Comisiei de etică universitară } \\
\text { abateri săvârșite de membri ai } \\
\text { comunității universitare. }\end{array}$ & $\begin{array}{l}\text { Articolul } 308 \\
\text { (1) Orice persoană, din universitate } \\
\text { sau din afara universității, poate } \\
\text { sesiza Comisiei de etică și } \\
\text { deontologie universitară abateri } \\
\text { săvârșite de membri ai comunității } \\
\text { universitare. } \\
\text { (11) Pentru abaterile care intră sub } \\
\text { incidența Legii } 206 \text { din } 2004 \text { privind } \\
\text { buna conduită în cercetarea } \\
\text { ştiințifică, dezvoltarea tehnologică } \\
\text { și inovare, termenul de prescripție } \\
\text { al depunerii unei sesizări este de } 1 \\
\text { an de la data la care autorul sesizării } \\
\text { a cunoscut săvârșirea abaterii. } \\
\text { Pentru celelalte abateri termenul } \\
\text { este de } 6 \text { luni de la data la care au } \\
\text { fost săvârșite, dacă autorul sesizării } \\
\text { este persoana vătămată, respectiv } \\
\text { de la data la care au fost cunoscute, }\end{array}$ \\
\hline
\end{tabular}




\begin{tabular}{|l|l|l|}
\hline & & $\begin{array}{l}\text { dacă autorul sesizării este o terță } \\
\text { persoană, dar fără a depăși un an de } \\
\text { la data săvârșirii. }\end{array}$ \\
\hline
\end{tabular}

Forma finală propusă pentru articolul 309 LEN, prin cumularea modificărilor de la nr. crt. 5 și 15.

\begin{tabular}{|c|c|c|c|}
\hline $\begin{array}{l}\text { Nr. } \\
\text { crt. }\end{array}$ & Articol & Text inițial & Text propus \\
\hline 15. & $\begin{array}{l}\text { Art. } 309 \text { LEN nr. } \\
1 / 2011\end{array}$ & $\begin{array}{l}\text { Articolul } 309 \\
\text { În urma unei sesizări, comisia de } \\
\text { etică universitară demarează proce- } \\
\text { durile stabilite de Codul de etică și } \\
\text { deontologie universitară, respectiv } \\
\text { de Legea nr. 206/2004, cu modi- } \\
\text { ficările și completările ulterioare. } \\
\text { Comisia răspunde autorului } \\
\text { sesizării în termen de } 30 \text { de zile de } \\
\text { la primirea sesizării și îi comunică } \\
\text { acestuia rezultatul procedurilor, } \\
\text { după încheierea acestora. }\end{array}$ & $\begin{array}{l}\text { Articolul } 309 \\
\text { (1) În urma unei sesizări, comisia de } \\
\text { etică universitară demarează proce- } \\
\text { durile stabilite de prezenta lege, de } \\
\text { Codul de etică și deontologie } \\
\text { universitară, respectiv de Legea } \\
\text { nr. 206/2004, cu modificările și } \\
\text { completările ulterioare. } \\
\text { (2) Comisia răspunde autorului } \\
\text { sesizării, soluționează și comunică } \\
\text { hotărârea părților în termen de } 45 \\
\text { de zile calendaristice de la primirea } \\
\text { sesizării. }\end{array}$ \\
\hline
\end{tabular}

Forma propusă pentru articolul $309^{1}$ LEN

\begin{tabular}{|c|c|c|c|}
\hline $\begin{array}{l}\text { Nr. } \\
\text { crt. }\end{array}$ & Articol & Text inițial & Text propus \\
\hline 6 & - & - & $\begin{array}{l}\text { Articolul 3091 } \\
\text { (1) La ședințele comisiei de etică } \\
\text { universitară, respectiv a comisiilor } \\
\text { de analiză, pot participa în calitate } \\
\text { de invitați, persoane cu experiență } \\
\text { în domeniul sesizării. } \\
\text { (2) Propunerea de invitare se } \\
\text { motivează, se poate face de către } \\
\text { orice membru al comisiei și se } \\
\text { aprobă cu votul majorității simple a } \\
\text { membrilor comisiei de etică } \\
\text { universitară. } \\
\text { (3) Persoanele invitate nu au drept } \\
\text { de vot. Opinia acestora este } \\
\text { consultativă și se menționează în } \\
\text { procesele verbale ale ședințelor la } \\
\text { care au participat. } \\
\text { (4) Poate avea calitatea de invitat } \\
\text { consilierul juridic al instituției. }\end{array}$ \\
\hline
\end{tabular}

\section{Forma finală propusă pentru articolul 318 lit.(e) LEN}

\begin{tabular}{|c|c|c|c|}
\hline $\begin{array}{l}\text { Nr. } \\
\text { crt. }\end{array}$ & Articol & Text inițial & Text propus \\
\hline 10. & $\begin{array}{l}\text { Art. } 318 \text { lit. (e) } \\
\text { LEN nr. } 1 / 2011\end{array}$ & $\begin{array}{l}\text { Articolul } 318 \\
\text { e) desfacerea disciplinară a } \\
\text { contractului de muncă }\end{array}$ & $\begin{array}{l}\text { Articolul } 318 \\
\text { e) destituirea din funcție }\end{array}$ \\
\hline
\end{tabular}


Forma finală propusă pentru articolul 321 LEN

\begin{tabular}{|c|c|c|c|}
\hline $\begin{array}{l}\text { Nr. } \\
\text { crt }\end{array}$ & Articol & Text inițial & Text propus \\
\hline 24. & $\begin{array}{c}\text { Art. 321, } \\
\text { LEN nr. 1/2011 }\end{array}$ & $\begin{array}{l}\text { Articolul } 321 \\
\text { În cazul abaterilor de la buna } \\
\text { conduită în cercetarea științifică, } \\
\text { comisia de etică universitară sta- } \\
\text { bilește, conform Legii nr. } 206 / 2004 \text {, } \\
\text { cu modificările și completările } \\
\text { ulterioare, Codului de etică și deon- } \\
\text { tologie profesională al personalului } \\
\text { de cercetare-dezvoltare și Codului } \\
\text { de etică și deontologie profe- } \\
\text { sională. }\end{array}$ & $\begin{array}{l}\text { Articolul } 321 \\
\text { În cazul abaterilor de la buna } \\
\text { conduită în cercetarea științifică, } \\
\text { comisia de etică și deontologie } \\
\text { universitară stabilește, conform } \\
\text { Legii nr. } 206 / 2004 \text {, cu modificările } \\
\text { și completările ulterioare, Codului } \\
\text { de etică și deontologie profesională } \\
\text { al personalului de cercetare- } \\
\text { dezvoltare și Codului de etică și } \\
\text { deontologie profesională. }\end{array}$ \\
\hline
\end{tabular}

Forma finală propusă pentru articolul 322 lit. (e) LEN

\begin{tabular}{|c|c|c|c|}
\hline $\begin{array}{l}\text { Nr. } \\
\text { crt. }\end{array}$ & Articol & Text inițial & Text propus \\
\hline 17. & $\begin{array}{c}\text { Art. } 322 \\
\text { Legea nr. } 1 / 2011\end{array}$ & $\begin{array}{l}\text { Articolul } 322 \\
\text { Sancțiunile stabilite de comisia de } \\
\text { etică și deontologie universitară } \\
\text { sunt puse în aplicare de către decan } \\
\text { sau rector, după caz, în termen de } \\
30 \text { de zile de la stabilirea } \\
\text { sancțiunilor. }\end{array}$ & $\begin{array}{l}\text { Articolul } 322 \\
\text { Sancțiunile stabilite de comisia de } \\
\text { etică și deontologie universitară } \\
\text { sunt puse în aplicare de către } \\
\text { rector, după caz, în termen de } 30 \text { de } \\
\text { zile de la stabilirea sancțiunilor. }\end{array}$ \\
\hline
\end{tabular}

Forma finală propusă pentru articolul 324 lit.(g) LEN

\begin{tabular}{|c|c|l|l|}
\hline $\begin{array}{c}\text { Nr. } \\
\text { crt. }\end{array}$ & Articol & \multicolumn{1}{|c|}{ Text inițial } & \multicolumn{1}{c|}{ Text propus } \\
\hline 11. & Art. 324 lit.(g) & $\begin{array}{l}\text { Articolul 324 } \\
\text { g) desfacerea disciplinară } \\
\text { contractului de muncă }\end{array}$ & $\begin{array}{l}\text { Articolul 324 } \\
\text { g) destituirea din funcție }\end{array}$ \\
\hline
\end{tabular}

2. FORMA FINALĂ A PROPUNERILOR DE MODIFICARE A ARTICOLELOR CUPRINSE ÎN LEGEA nr. 206/2004

Forma finală propusă pentru articolul 9 alin. (2), (21), (3) și (3 $\left(^{1}\right)$ Legea nr. 206/2004.

\begin{tabular}{|c|c|c|c|}
\hline $\begin{array}{l}\text { Nr. } \\
\text { crt. }\end{array}$ & Articol & Text inițial & Text propus \\
\hline 2. & $\begin{array}{l}\text { Art. } 9 \text { alin. (2) și } \\
\text { (3), Legea } \\
\text { nr. 206/2004 }\end{array}$ & $\begin{array}{l}\text { Articolul } 9 \\
\text { (2) În cadrul unităților şi al } \\
\text { instituțiilor prevăzute la alin. (1) se } \\
\text { înființează comisii de etică, pe } \\
\text { lângă consiliile științifice sau, după } \\
\text { caz, pe lângă consiliile de } \\
\text { administrație } \\
\text { (3) Componența comisiilor de etică } \\
\text { este propusă de consiliile științifice } \\
\text { sau, după caz, de consiliile de }\end{array}$ & $\begin{array}{l}\text { (2) În cadrul unităților şi al } \\
\text { instituțiilor de cercetare prevăzute } \\
\text { la alin. (1) se înființează comisii de } \\
\text { etică, pe lângă consiliile ştiințifice } \\
\text { sau, după caz, pe lângă consiliile de } \\
\text { administrație. } \\
\left(2^{1}\right) \text { În cadrul instituțiilor de } \\
\text { învățământ superior prevăzute la } \\
\text { alin. (1) se înființează comisii de } \\
\text { etică, ca organism decizional, }\end{array}$ \\
\hline
\end{tabular}




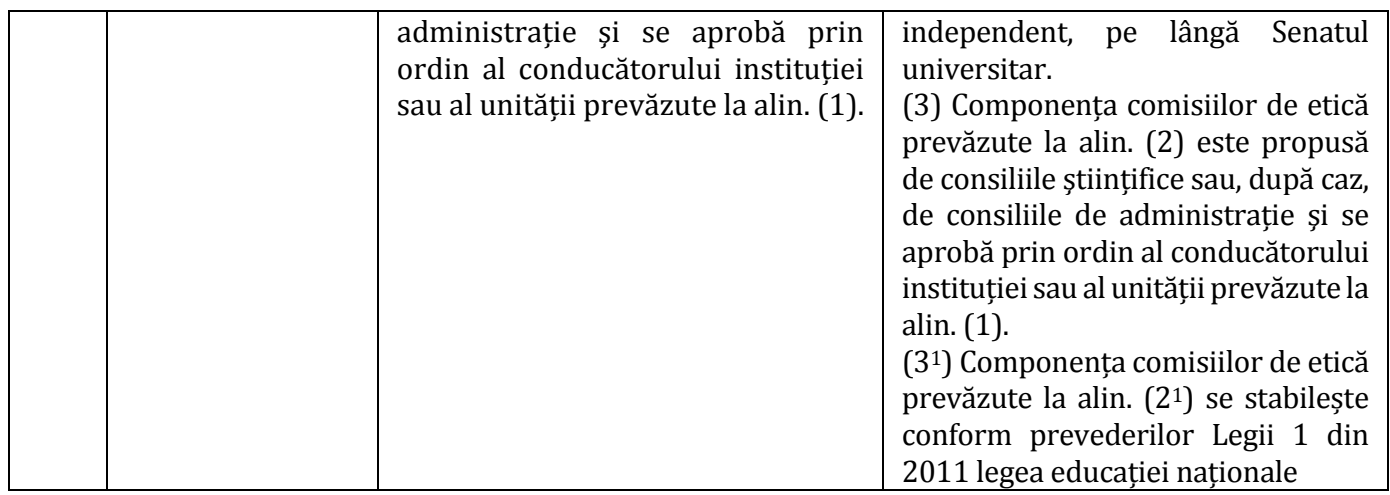

Forma finală propusă pentru articolul 11 Legea nr. 206/2004, prin cumularea modificărilor de la nr. crt. 7 și 14.

\begin{tabular}{|c|c|c|c|}
\hline $\begin{array}{l}\text { Nr. } \\
\text { crt. }\end{array}$ & Articol & Text inițial & Text propus \\
\hline $\begin{array}{l}7 . \\
\text { si } \\
14 .\end{array}$ & $\begin{array}{c}\text { Art. } 11 \\
\text { Legea } \\
\text { nr. } 206 / 2004\end{array}$ & $\begin{array}{l}\text { Articolul 11 } \\
\text { (1) Procedurile pe care comisia de } \\
\text { etică, respectiv comisia de analiză le } \\
\text { desfăşoară în cazul sesizărilor } \\
\text { scrise, inițiate de persoane fizice sau } \\
\text { juridice cunoscute, ori în urma } \\
\text { autosesizării sunt detaliate în Codul } \\
\text { de etică, cu respectarea prevede- } \\
\text { rilor prezentei legi. } \\
\text {--- } \\
\text { (3) Comisia de analiză elaborează } \\
\text { un raport care se aprobă de către } \\
\text { comisia de etică, se comunică } \\
\text { autorului sesizării în scris şi se face } \\
\text { public pe site-ul web al instituției în } \\
\text { termen de } 45 \text { de zile calendaristice } \\
\text { de la primirea sesizării; în cazul } \\
\text { constatării unor abateri de la } \\
\text { normele de bună conduită în } \\
\text { activitatea de cercetare-dezvoltare, } \\
\text { raportul numeşte persoanele } \\
\text { vinovate şi stabilește una sau mai } \\
\text { multe dintre sancțiunile prevăzute } \\
\text { la art. } 11^{\wedge} 1 ; \text { persoanele vinovate pot } \\
\text { fi diferite de persoanele vizate în } \\
\text { textul sesizării. } \\
\text { (3) Comisia de analiză elaborează un } \\
\text { raport care se aprobă de către } \\
\text { comisia de etică, se comunică auto- } \\
\text { rului sesizării în scris şi se face public } \\
\text { pe site-ul web al instituției în termen } \\
\text { de } 45 \text { de zile calendaristice de la } \\
\text { primirea sesizării; în cazul consta- } \\
\text { tării unor abateri de la normele de } \\
\text { bună conduită în activetatea de }\end{array}$ & $\begin{array}{l}\text { Articolul 11 } \\
\text { (1) Procedurile pe care comisia de } \\
\text { etică, respectiv comisia de analiză le } \\
\text { desfaşoară în cazul sesizărilor } \\
\text { scrise, inițiate de persoane fizice sau } \\
\text { juridice cunoscute, ori în urma } \\
\text { autosesizării sunt detaliate în Codul } \\
\text { de etică, cu respectarea prevede- } \\
\text { rilor prezentei legi. } \\
\text { (11) Termenul de prescripție al } \\
\text { depunerii unei sesizări este de } 1 \text { an } \\
\text { de la data la care autorul sesizării a } \\
\text { cunoscut săvârşirea abaterii. } \\
\text {-- } \\
\text { (3) Comisia de analiză elaborează } \\
\text { un raport care se aprobă prin } \\
\text { hotărâre de către comisia de etică, } \\
\text { se comunică ipărților, în scris, şi se } \\
\text { face publice pe site-ul web al } \\
\text { instituției în termen de } 45 \text { de zile } \\
\text { calendaristice de la primirea } \\
\text { sesizării; în cazul constatării unor } \\
\text { abateri de la normele de bună } \\
\text { conduită în activitatea de cercetare- } \\
\text { dezvoltare, raportul numește } \\
\text { persoanele vinovate şi stabilește } \\
\text { una sau mai multe dintre sancțiunile } \\
\text { prevăzute la art. } 11^{\wedge} 1 \text {; persoanele } \\
\text { vinovate pot fi diferite de } \\
\text { persoanele vizate în textul sesizării. } \\
\text { (31) Raportul comisie de analiză } \\
\text { face parte integrantă din hotărârea } \\
\text { comisiei de etică. } \\
\text { (32) În termen de } 10 \text { zile de la } \\
\text { emiterea hotărârii comisiei de etică, }\end{array}$ \\
\hline
\end{tabular}




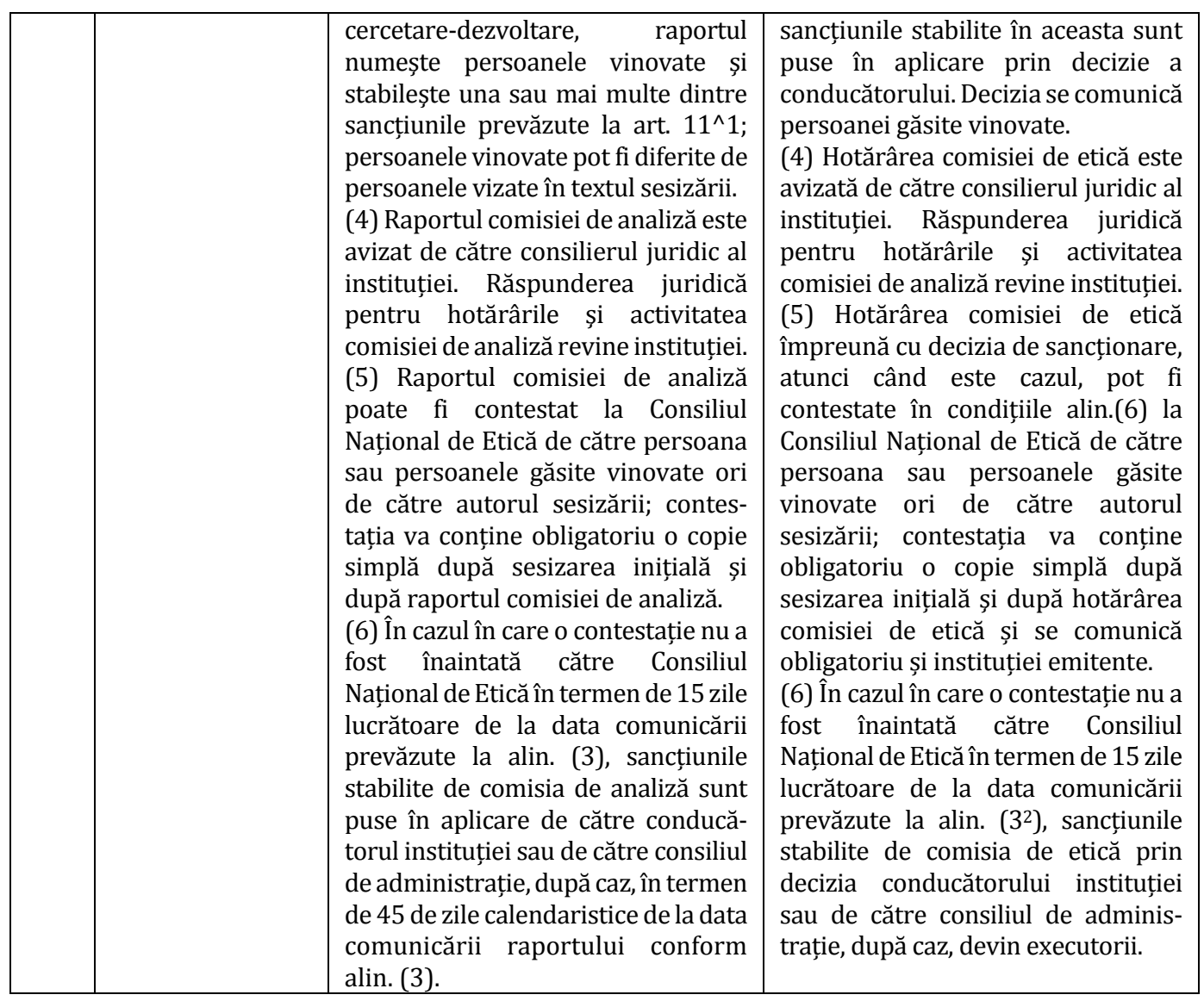

Forma finală propusă pentru articolul 11^1 lit. f) Legea nr. 206/2004.

\begin{tabular}{|c|c|c|c|}
\hline $\begin{array}{l}\text { Nr. } \\
\text { crt. }\end{array}$ & Articol & Text inițial & Text propus \\
\hline 12. & $\begin{array}{l}\text { Art. } 11^{\wedge} 1 \text { lit. (f) } \\
\text { din Legea } \\
\text { nr. } 206 / 2004\end{array}$ & $\begin{array}{l}\text { Articolul 11^1 } \\
\text { f) desfacerea disciplinară a } \\
\text { contractului de muncă }\end{array}$ & $\begin{array}{l}\text { Articolul 11^1} \\
\text { f) destituirea din funcție }\end{array}$ \\
\hline
\end{tabular}

\section{FORMA FINALĂ A PROPUNERILOR DE MODIFICARE A ARTICOLELOR CUPRINSE ÎN REGULAMENTUL DE ORGANIZARE ȘI FUNCTIIONARE AL CNECSDTI, APROBAT PRIN ORDINUL 4655 DIN 2020}

\begin{tabular}{|c|c|l|l|}
\hline 8. & Articolul 21 & Articolul 21 & Articolul 21 \\
& Regulamentul de & (1) CNECSDTI este obligat să & (1) CNECSDTI este obligat să \\
& organizare și & analizeze cazurile sesizate în & analizeze cazurile sesizate în \\
& funcționare al & oricare dintre următoarele situații: & oricare dintre următoarele situații: \\
& CNECSDTI, & a) atunci când la sesizare sau & a) atunci când la sesizare sau \\
& aprobat prin & contestație este anexată o copie & contestație este anexată o copie \\
& Ordinul 4655 din & simplă, în format scris ori & simplă, în format scris ori \\
& 2020 & electronic, după raportul elaborat & electronic, după hotărârea comisiei \\
\hline
\end{tabular}




\begin{tabular}{|l|l|l|l|}
\hline & $\begin{array}{l}\text { de către comisia de analiză din } \\
\text { cadrul unității sau instituției în } \\
\text { care presupusa abatere s-a produs; }\end{array}$ & $\begin{array}{l}\text { de etică care cuprinde și raportul } \\
\text { elaborat de către comisia de } \\
\text { analiză din cadrul unității sau } \\
\text { instituției în care presupusa } \\
\text { abatere s-a produs; }\end{array}$ \\
\hline
\end{tabular}

4. FORMA FINALĂ A PROPUNERILOR DE MODIFICARE A ARTICOLELOR CUPRINSE ÎN METODOLOGIA PRIVIND SOLUȚIONAREA SESIZĂRILOR CU PRIVIRE LA NERESPECTAREA STANDARDELOR DE CALITATE SAU DE ETICĂ PROFESIONALĂ, INCLUSIV CU PRIVIRE LA EXISTENȚA PLAGIATULUI, ÎN CADRUL UNEI TEZE DE DOCTORAT, APROBATĂ PRIN ORDINUL $5229 / 2020$.

\begin{tabular}{|c|c|c|c|}
\hline 16. & $\begin{array}{l}\text { Art. } 6 \text { lit. e) din } \\
\text { Metodologia } \\
\text { privind soluțio- } \\
\text { narea sesizărilor } \\
\text { cu privire la } \\
\text { nerespectarea } \\
\text { standardelor de } \\
\text { calitate sau de } \\
\text { etică profesio- } \\
\text { nală, inclusiv cu } \\
\text { privire la exis- } \\
\text { tența plagiatului, } \\
\text { în cadrul unei } \\
\text { teze de doctorat, } \\
\text { aprobată prin } \\
\text { Ordinul } \\
5229 / 2020\end{array}$ & $\begin{array}{l}\text { Articolul } 6 \\
\text { e) punctul de vedere al IOSUD/IOD, } \\
\text { care este consultativ și se referă la } \\
\text { propunerea de menținere/retragere } \\
\text { a titlului de doctor, semnată de } \\
\text { rector sau, după caz, de președintele } \\
\text { Academiei Române, documentele și } \\
\text { reglementările interne, în vigoare la } \\
\text { data înmatriculării la doctorat a } \\
\text { autorului tezei de doctorat și apli- } \\
\text { cabile la data susținerii publice, care } \\
\text { au fundamentat această propunere, } \\
\text { în principal hotărârea Comisiei de } \\
\text { etică universitară, avizată juridic, și } \\
\text { la alte măsuri interne stabilite în } \\
\text { cazul în care s-a constatat încălcarea } \\
\text { eticii universitare; }\end{array}$ & $\begin{array}{l}\text { Articolul } 6 \\
\text { e) punctul de vedere al IOSUD/IOD, } \\
\text { care este consultativ și se referă la } \\
\text { propunerea de menținere/retragere } \\
\text { a titlului de doctor, semnată de } \\
\text { rector sau, după caz, de președintele } \\
\text { Academiei Române, documentele și } \\
\text { reglementările interne, în vigoare la } \\
\text { data înmatriculării la doctorat a } \\
\text { autorului tezei de doctorat și apli- } \\
\text { cabile la data susținerii publice, care } \\
\text { au fundamentat această propunere, } \\
\text { existența unei hotărâri a Comisiei de } \\
\text { etică universitară, avizată juridic, și } \\
\text { la alte măsuri interne stabilite în } \\
\text { cazul în care s-a constatat încălcarea } \\
\text { eticii universitare; }\end{array}$ \\
\hline
\end{tabular}

Documentul a fost realizat și comunicat către CEMU de către:

Cristina SALCĂ ROTARU

Președinte al Comisiei de etică și deontologie universitară

Universitatea Transilvania din Brașov

Lect. dr. Facultatea de Drept

Universitatea Transilvania din Brașov

\section{Laura MANEA}

Consilier juridic

Universitatea Transilvania din Brașov Lect. dr. Facultatea de Drept Universitatea Transilvania din Brașov 


\section{INDICE AUTORI}

$\begin{array}{ll}\text { CîRSTEA Nicolae } & -7 \\ \text { COCUZ luliu-Gabriel } & -74 \\ \text { COCUZ Maria-Elena } & -74 \\ \text { de CARVALHO FIGUEIREDO Frederico } & -104 \\ \text { DEACONU Marius } & -25 \\ \text { DINU Cătălina-Georgeta } & -82 \\ \text { DîRJA Marcel } & -52 \\ \text { GIURGIUMAN Tünde } & -25,52 \\ \text { HOVHANNISYAN Gayane } & -10 \\ \text { INGLIS Iulia } & -95 \\ \text { IVAN Angela Stela } & -18 \\ \text { KHECHOYAN Tereza } & -10 \\ \text { LUPU Gabriel-Stănică } & -44 \\ \text { MANEA Laura } & -7,32,104,117 \\ \text { MAROZ Nataliya } & -60 \\ \text { MURZEA Cristinel loan } & -89 \\ \text { SALCĂ ROTARU Cristina Mihaela } & -7,32,52,117 \\ \text { SLABU Elisabeta } & -18 \\ \text { VÂTCĂ Sorin Daniel } & -25,52\end{array}$

